U.S. Department

of Transportation

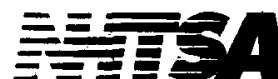

Nerional righwory

People Saving Peoplo

Truffic Safohy

wrm.nhtsa.dot.gor

DOT HS 809020

March 2000

\title{
Visual Search and Urban City Driving under the Influence of Marijuana and Alcohol
}

This document is available to the public from the National Technical Information Service, Springfield, Virginia 22161 


\section{Visual Search and Urban City Driving under the Influence of Marijuana and Alcohol}

CTJ Lamers and JG Ramaekers

Experimental Psychopharmacology Unit

Brain \& Behavior Institute, Maastricht University

The Netherlands 
Technical Report Documentation Page

\begin{tabular}{|c|c|}
\hline $\begin{array}{l}\text { 1. Report No. } \\
\text { DOT HS } 809020\end{array}$ & 3. Recipient's Catalog No. \\
\hline $\begin{array}{l}\text { 4. Title and Subtitle } \\
\text { Visual Search and Urban City Driving Under the Influence } \\
\text { of Marijuana and Aclohol }\end{array}$ & $\begin{array}{l}\text { 5. Report Date } \\
\text { March } 2000 \\
\text { 6. Performing Organization Code } \\
\text { EPU }\end{array}$ \\
\hline $\begin{array}{l}\text { 9. Performing Agency Name and Address } \\
\text { Experimental Psychopharmacology Unit, } \\
\text { Brain and Behavior Institute } \\
\text { Maastricht University }\end{array}$ & 10. Work Unit No. (TRAIS) \\
\hline United States of America and The Netherlands. & 14. Sponsoring Agency Code \\
\hline
\end{tabular}

15. Supplementary Notes

\section{Abstract}

The purpose of this study was to empirically determine the separate and combined effects of delta-9-tetrahydrocannabinol (THC) and alcohol on visual search and actual city driving performance. On separate evenings, sixteen subjects were given weight-calibrated doses of THC and alcohol, or placebos for one of both substances as follows: alcohol placebo + THC placebo, alcohol + THC placebo, THC $100 \mathrm{~g} / \mathrm{kg}+$ alcohol placebo, THC $100 \mathrm{~g} / \mathrm{kg}+$ alcohol. Alcohol doses administered were sufficient for achieving blood alcohol concentrations of about $0.05 \mathrm{~g} / \mathrm{dl}$.

The City Driving Test commenced $15 \mathrm{~min}$ after smoking and lasted 45 minutes. The test was conducted over a fixed route within the city limits of Maastricht. An eye movement recording system was mounted on the subjects' head for providing relative frequency measures of appropriate visual search at intersections. General driving quality was rated by a licensed driving instructor. After placebo treatments subject looked at side streets from the right in 848 of all cases. Visual search frequency of these subjects did not change when treated with alcohol or marijuana alone. However when treated with the combination of alcohol and marijuana the frequency of visual search dropped by 3\%. Performance as rated on the Driving Proficiency Scale did not differ between treatments. It was concluded that the effects of low doses of THC (100 $\mathrm{g} / \mathrm{kg}$ ) and alcohol (BAC<0.05 $\mathrm{g} / \mathrm{dl}$ ) on visual search and general driving proficiency are minimal when taken alone, but potentially dangerous for traffic safety when taken in combination.

\section{Key Words}

Alcohol, marijuana, THC, city driving performance, visual search, traffic safety, drugs and driving
18. Distribution Statement

Document available to the public through the National Technical Information Service, Springfield, VA 22161

\begin{tabular}{|l|l|l|l|}
\hline $\begin{array}{l}\text { 19. Security Classif. (of this report) } \\
\text { Unclassified }\end{array}$ & 20. SECURITY CLASSIF. (of this page) & 21. No. of Pages & 22. Price \\
Unclassified
\end{tabular}




\section{CONTENTS}

SUMMARY 3

$1 \quad$ INTRODUCTION 4

2 METHODS $\quad 7$

$\begin{array}{lll}2.1 & \text { Subjects } & 7\end{array}$

$\begin{array}{lll}2.2 & \text { Design, doses and administration } & 8\end{array}$

$\begin{array}{lll}2.3 & \text { Testing procedure } & 9\end{array}$

$\begin{array}{lll}2.4 & \text { The City Driving Test } & 10\end{array}$

$\begin{array}{ll}2.5 & \text { Route Recognition Test } \\ \end{array}$

$\begin{array}{lll}2.6 & \text { Questionnaires } & 12\end{array}$

$\begin{array}{lll}2.7 & \text { Statistical analyses } & 13\end{array}$

$\begin{array}{lll}3 & \text { RESULTS } & 14\end{array}$

$\begin{array}{lll}3.1 & \text { Missing data } & 14\end{array}$

$\begin{array}{lll}3.2 \text { Intoxication } & 14\end{array}$

$\begin{array}{lll}3.3 & \text { Driving performance } & 15\end{array}$

$\begin{array}{lll}3.4 & \text { Route recognition } & 16\end{array}$

$\begin{array}{lll}3.5 \text { Questionnaires } & 16\end{array}$

$4 \cdot$ DISCUSSION 19

5 CONCLUSIONS 23

6 REFERENCES $\quad 24$

APPENDICES 


\section{SUMMARY}

The purpose of the present study was to assess the effects of low doses of marijuana and alcohol, and their combination on visual search at intersections and general driving proficiency in a City Driving Test. Sixteen recreational users of alcohol and marijuana

( 8 males and 8 females) were treated with these substances and placebo according to a balanced, 4-way, cross-over, observer- and subject-blind design. On separate evenings, subjects received weight-calibrated doses of THC, alcohol or placebo in each of the following treatment conditions: alcohol placebo + THC placebo, alcohol + THC placebo, THC 100 $\mu \mathrm{g} / \mathrm{kg}+$ alcohol placebo, THC $100 \mu \mathrm{g} / \mathrm{kg}+$ alcohol. Alcohol doses administered were sufficient for achieving blood alcohol concentrations of about $0.05 \mathrm{~g} / \mathrm{dl}$. Initial drinking preceded smoking by one hour. The City Driving Test commenced 15 minutes after smoking and lasted 45 minutes. The test was conducted over a fixed route within the city limits of Maastricht. An eye movement recording system was mounted on the subjects' head for providing relative frequency measures of appropriate visual search at intersections. General driving quality was rated by a licensed driving instructor on a shortened version of the Royal Dutch Tourist Association's Driving Proficiency Test. After placebo treatment subjects looked at side streets from the right in $84 \%$ of all cases. Visual search frequency of these subjects did not change when treated with alcohol or marijuana alone. However, when treated with the combination of alcohol and marijuana, the frequency of visual search dropped by $3 \%$. Performance as rated on the Driving Proficiency Scale did not differ between treatments. It was concluded that the effects of low doses of THC $(100 \mu \mathrm{g} / \mathrm{kg})$ and alcohol $(\mathrm{BAC}<0.05 \mathrm{~g} / \mathrm{dl})$ on visual search and general driving proficiency are minimal when taken alone, but potentially dangerous for traffic safety when taken in combination. 


\section{INTRODUCTION}

Findings from the 1996 National Household Survey of Drug Abuse (NHSDA) suggest that more than a quarter of the 166 million drivers age 16 and older in the United States occasionally drive under the influence of alcohol and/or marijuana (Townsend et al, 1998). Twenty-three percent of the 11,847 NHSDA respondents, representing 38 million drivers, reported that they had driven within two hours after alcohol abuse in the past year. Four percent of the respondents, representing approximately 8.9 million people, reported driving following the use of marijuana. In addition, more than $80 \%$ of the latter reported the combined use of marijuana and moderate doses of alcohol (BAC $<0.08 \mathrm{~g} / \mathrm{dl}$ ). These drivers subjectively felt that marijuana with or without alcohol did not affect their ability to drive safely or their likelihood of being stopped by the police.

Subjective impressions should never be taken as conclusive evidence for determining the effect of $\Delta^{9}$-tetrahydrocannabinol (THC) on driving ability, especially since most epidemiological surveys have revealed the presence of marijuana in roughly $4-12 \%$ of drivers injured or killed in traffic accidents (Cimbura et al, 1980, 1982; Terhune, 1982; Chester \& Starmer, 1983; Donelson et al, 1985, Garriot et al, 1986, Daldrup et al, 1987, McClean et al, 1987; Williams et al, 1985; Soderstrom et al, 1988; Budd et al, 1989; Terhune et al, 1992). If the population at risk is indeed about $4 \%$ as indicated by the NHSDA survey, this injury/fatality rate must be taken to indicate that the drugs' users are overrepresented among crash victims. It is dubious however if THC was the only factor responsible for the crashes, because alcohol was also present in the majority of survey victims showing any plasma concentration of THC. It is highly likely that THC in combination with alcohol possesses a greater risk potential than either of these substances alone. 
Several experimental studies have been conducted to assess the separate and combined effects of THC and alcohol in driving simulators (Smiley et al, 1981; Stein et al, 1983), closed-course driving tests (Caswell, 1979, Attwood 1981, Smiley et al, 1987, Peck et al, 1986) and driving tests in normal traffic (Robbe, 1998; Robbe \& O'Hanlon, 1999). To a large extend, the results from experimental studies are in line with epidemiological findings. They indicate that $\mathrm{THC}$ in single doses up to $250 \mu \mathrm{g} / \mathrm{kg}$ has relatively minor effects on driving performance, certainly less than BACs in the range of 0.08 to $0.10 \mathrm{~g} / \mathrm{dl}$. The combined effects of THC doses and social doses of alcohol were essentially additive. They were no greater than the sum of effects that each drug produced separately. Still, the magnitude of impairment observed after combinations of THC and alcohol were sometimes large. Robbe \& O'Hanlon (1999) showed that low-moderate THC doses combined with low alcohol doses are as, or more, impairing than BACs around the legal limit (0.08 $\mathrm{g} / \mathrm{dl}$ in several American states). In his study, doses of $100 \mu \mathrm{g} / \mathrm{kg}$ and $200 \mu \mathrm{g} / \mathrm{kg}$ THC, in combination with small amounts of alcohol (BAC $<0.04 \mathrm{~g} / \mathrm{dl})$, impaired highway driving performance in a road tracking test and a car-following test to a degree previously observed in social drinkers conducting the same tests with $\mathrm{BACs}$ of $0.09 \mathrm{~g} / \mathrm{dl}$ and $0.14 \mathrm{~g} / \mathrm{dl}$ respectively.

The objective of the present study was to determine whether a low dose of THC in combination with a low dose of alcohol would also have a significant effect on driving performance in a more complex urban environment. The approach taken in this study represents a combination of a retrospective expert rating for assessing drug effects on city driving performance, and measurement of visual search at intersections through eye movement recordings. The method of using a retrospective expert rating has previously been applied to show the impairing effects of alcohol and diazepam (De Gier, 1979, De Gier, 1981, Robbe, 1994) and the lack of impairing effects of low THC doses (70-120 $\mu \mathrm{g} / \mathrm{kg})$ on driving 
performance (Klonoff, 1974, Robbe, 1994). Klonoff did find some reduction in the subjects' scores on judgment and concentration under the influence of $120 \mu \mathrm{g} / \mathrm{kg}$ THC, but behaviors that were more directly related to driving performance were unaffected by THC in both studies.

The rationale for measuring visual search at intersections is that many researchers have demonstrated that THC causes attentional deficits in dual-task situations (Moskowitz, 1985; Barnett et al, 1985; Heisman et al, 1989; Azorlosa et al, 1992; Perez-Reyes et al, 1988; Marks \& MacAvoy, 1989). Dual-tasks or divided-attention tasks involve the detection of peripheral signals by subjects that simultaneously perform a task presented on a central display, such as pursuit tracking or counting light flashes. Under the influence of THC subjects were less able to conduct central and peripheral tasks simultaneously. This adverse effect was most notable in the peripheral visual search tasks. It might indicate that drivers under the influence of THC apply their attention more specifically to the main road, while partially neglecting traffic coming from the side roads. Such narrowing of the attentional field might become particularly dangerous when the driver crosses intersections without right of way, as in many urban or suburban areas. 


\section{METHODS}

\subsection{Subjects}

Sixteen subjects ( 8 males and 8 females) between 21 and 40 years of age participated in the study. Initial screening was accomplished on the basis of a medical/driving experience questionnaire. Qualified individuals were examined by the Medical Supervisor who also obtained vital signs, blood and urine samples. Standard blood chemistry, hematology and drug screen tests were conducted on these samples. Inclusion criteria were the possession of a valid driving license for at least three years, driving experience of at least $5000 \mathrm{~km}$ per year, experience driving at least once while under the influence of marijuana in the preceding year, Dutch nationality, normal binocular vision (corrected or uncorrected), body weight within $15 \%$ percent of the average for individual's height and weight, use of marijuana and alcohol more than once a month but less than daily and informed consent in writing. Exclusion criteria were a history of treatment for drug or alcohol abuse or current addiction, record of arrest or conviction for drunken driving or drug trafficking, history of psychiatric, neurological, cardiovascular, respiratory, metabolic, hepatic or renal disorders, current use of psychoactive

Table 1 Mean \pm SD ( range) of the subject's characteristics

\begin{tabular}{lcccccc}
\hline & \multicolumn{2}{c}{ males } & \multicolumn{2}{c}{ females } & \multicolumn{2}{c}{ Total } \\
\hline & mean $\pm \mathrm{SD}$ & range & mean $\pm \mathrm{SD}$ & range & mean \pm SD & range \\
\hline age (yrs) & $22.9 \pm 2.0$ & $21-26$ & $24.3 \pm 3.6$ & $21-32$ & $23.6 \pm 2.9$ & $21-32$ \\
weight (kg) & $74.4 \pm 9.6$ & $62-87$ & $61.7 \pm 2.6$ & $59-68$ & $68.0 \pm 9.4$ & $59-87$ \\
driving experience (yrs) & $4.3 \pm 1.8$ & $3-7$ & $5.3 \pm 2.7$ & $3-11$ & $4.8 \pm 2.2$ & $3-11$ \\
driving experience & $48 \pm 39.7$ & $15-140$ & $42.4 \pm 30.0$ & $15-100$ & $45.2 \pm 34.1$ & $15-140$ \\
(x 1000km) & & & & & & \\
\# THC cigarettes/month & $10.4 \pm 9.1$ & $2-24$ & $2.8 \pm 2.1$ & $2-8$ & $6.6 \pm 7.5$ & $2-24$ \\
\# alcohol/week & $13.1 \pm 7.2$ & $2-25$ & $9.3 \pm 5.1$ & $2-15$ & $11.2 \pm 6.4$ & $2-25$ \\
\hline
\end{tabular}


medication, and pregnancy. Characteristics of 16 subjects who entered the study are displayed in Table 1.

The study's protocol was reviewed and approved by the Medical Ethics Committee of the University of Maastricht and the District Attorney of Maastricht. The subjects were treated according to the code of ethics on human experimentation stated by the Declaration of Helsinki (1964) and its subsequent amendments.

\subsection{Design, doses and administration}

The study followed a 4-way, observer and subject blind, cross-over design. Treatment orders were balanced and randomly assigned from those residing in four, $4 \times 4$, William Squares (Winer, 1962). A minimum wash-out period of 7 days transpired between treatments.

Subjects began treatment by drinking alcohol or alcohol-placebo. Then, they smoked marijuana-placebo or marijuana delivering THC in a dose of $100 \mu \mathrm{g} / \mathrm{kg}$. All four combinations of alcohol and THC were consumed on separate occasions: alcohol-placebo + marijuana-placebo (PLA), alcohol placebo $+100 \mu \mathrm{g} / \mathrm{kg}$ THC (THC), alcohol + marijuana placebo (ALC), and alcohol $+100 \mu \mathrm{g} / \mathrm{kg} \mathrm{THC} \mathrm{(ALC/THC).}$

Alcohol was administered as $99.8 \%$ ethanol mixed with orange juice to a volume of 300 $\mathrm{ml}$, and consumed within 15 minutes after the consumption of a standard meal that consisted of two sandwiches. The alcohol doses for males and females were $0.5 \mathrm{~g} / \mathrm{kg}$ and $0.43 \mathrm{~g} / \mathrm{kg}$ body weight respectively. These were chosen to yield a BAC of $0.04-0.05 \mathrm{~g} / \mathrm{dl}$ at the beginning of the driving test. Subjects' BAC were monitored at 15 minutes intervals for 1 hour after drinking using a Lion SD-4 Breath-Alcohol Analyzer. Those failing to reach the expected peak were given a booster dose of $0.05-0.02 \mathrm{~g} / \mathrm{kg}$ in the same proportion to the mixer at 45 minutes after the first dose, whereas others were given the mixer alone. 
Smoking followed drinking by 45 minutes and lasted for about 5 minutes. The cigarettes were prepared beforehand for each individual from stock provided by the National Institute of Drug Abuse of the United States. Marijuana cigarettes were prepared from batches containing $2.2 \%$ THC. They were cut to provide length appropriate for the subjects' body weight. Placebo cigarettes were similarly shortened.

\subsection{Testing procedure}

Two subjects were tested per day. After their arrival at the laboratory at 7:00 PM and 8:00 PM respectively, subjects were tested for the presence of alcohol and drugs (i.e., methadone, cocaine, amphetamines, opiates, cannabinoids, benzodiazepines and tryciclic antidepressants) in breath and urine respectively. Drinking and smoking commenced at 70 and 25 minutes prior to onset of the driving test respectively. Smoking was directly followed by drinking of the booster dose. Subjects' BACs were determined at onset and conclusion of the City Driving Test (duration 40 minutes) while completing a number of questionnaires. Finally, subjects conducted a route recognition test at 15 minutes after the conclusion of the driving test.

Successive test sessions were ordinarily scheduled for particular subjects at weekly intervals. They were forbidden to smoke marijuana or hashish outside the study, or to take any other illicit drug, from 7 days before their first session until the conclusion of the last. They were told that detection of any drug in urine samples provided at the beginning of a session would cause their immediate dismissal. They were similarly forbidden to drink alcohol for 24 hrs before sessions. They were instructed to retire for and arise from sleeping at normal times. Consumption of beverages containing caffeine was prohibited during sessions. 


\subsection{The City Driving Test}

The City Driving Test in the current study largely followed standard procedures from a previous version (Robbe, 1994). Driving tests were conducted in the evening over a constant route $( \pm 15 \mathrm{~km})$ within the city of Maastricht. The route was constructed through business and residential areas on 2-lane undivided streets and included a $5 \mathrm{~km}$ 4-lane divided segment on a major cross-city thoroughfare. Maneuvers included left and right turns at some intersections and driving through others, left and right lane changes, responding to traffic control devices, and a turn on a residential street.

A shortened version of the Royal Dutch Tourist Association (ANWB) Driving Proficiency Test was used for rating the drivers' performance in retrospect. In total, 90 items were scored dichotomously as either pass or fail. Total test performance was scored by the percentage of items scored as 'pass'. Subscores were calculated for vehicle checks, vehicle handling, traffic maneuvers, observation and understanding traffic, and turning. A summary of dependent variables measured by the Driving Proficiency Test is given in Table 2.

Eye movements were recorded during all tests using a head mounted eye tracking system (4000SU Eye Tracker, Applied Science Laboratories, Bedford, MA, USA). The eye-

Table 2 Dependent variables, and their operationalization, measured in the Driving Proficiency Test

\begin{tabular}{ll}
\hline dependent variable & operationalization \\
\hline $\begin{array}{c}\text { Total score } \\
\text { vehicle checks }\end{array}$ & $\begin{array}{l}\text { sum of score of all } 90 \text { items } \\
\text { sum of score of } 11 \text { items comprising 'adjusting mirrors'and 'starting the } \\
\text { engine' 'driving away' } \\
\text { sum of score of } 24 \text { items comprising 'path' and 'speed adjustment and } \\
\text { stopping' 'driving through curves' } \\
\text { sum of score of } 42 \text { items comprising 'intersections', 'gap acceptance', } \\
\text { 'driving in lanes', 'changing lanes' and 'left or right turns' } \\
\text { sum of score of } 8 \text { items comprising 'traffic insight' and 'perception' }\end{array}$ \\
$\begin{array}{l}\text { traffic maneuvers } \\
\text { observation and under- } \\
\text { standing traffic } \\
\text { special maneuvers }\end{array}$ & $\begin{array}{l}\text { sum of score of } 5 \text { items regarding 'turn location and backing', and 'shut- } \\
\text { down' }\end{array}$ \\
\hline
\end{tabular}


tracker is designed to accurately measure a freely moving subject's eye line of gaze with respect to the head. The eye is illuminated by the beam from an infra-red light source and an optical system focuses an image of the pupil onto a solid state eye camera. Both the illumination beam and the image of the eye are reflected from a helmet visor which is coated to be reflective in the near infrared region and transitive to visible light. Pupil and corneal

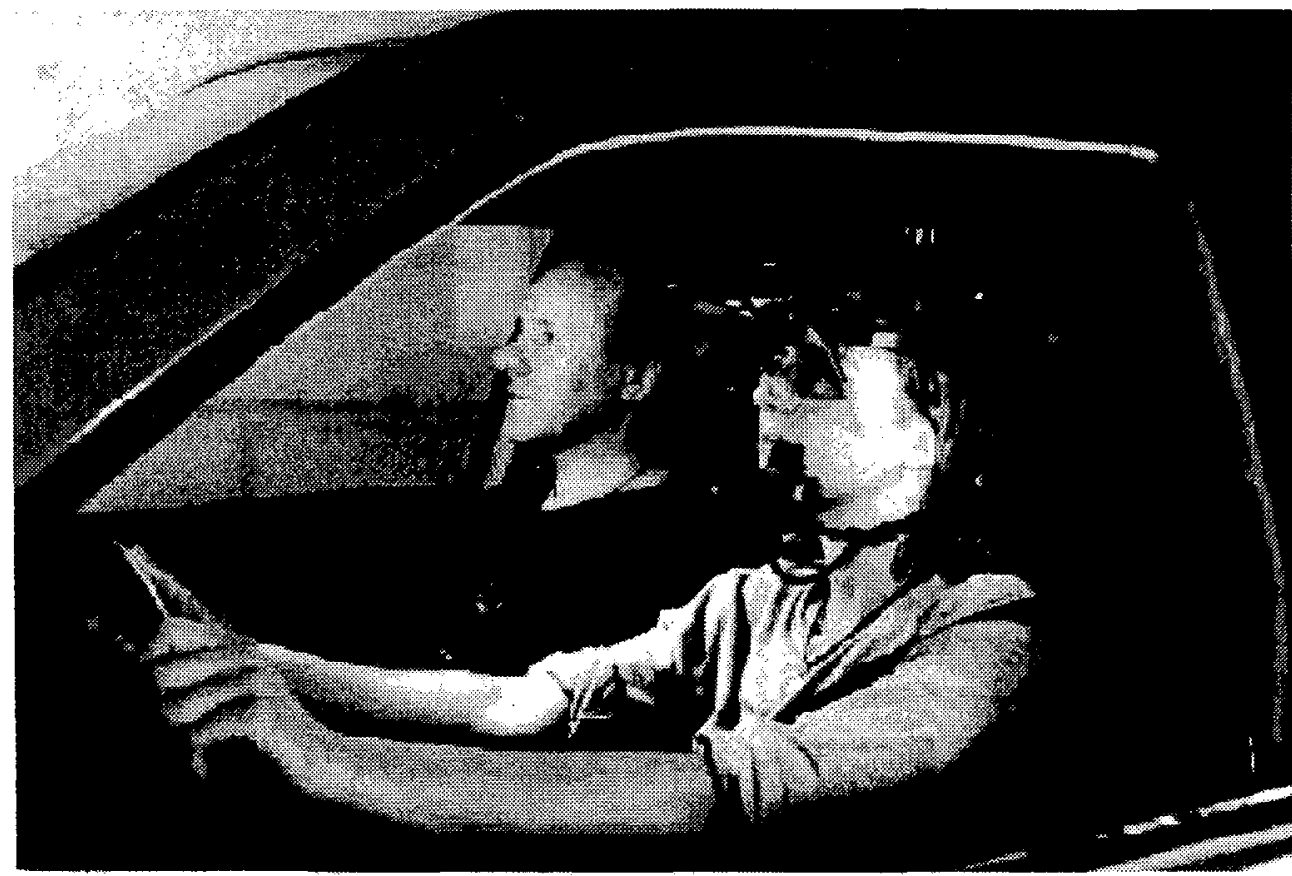

Figure 1 The eye tracking system mounted on a subject's head. A licensed driving instructor controlled safety during the driving tests

reflection outlines and centroids (i.e. centers of reflection marked by crosshairs) are displayed on a pupil monitor over the video image of the eye. A second miniature camera is focused on the forward visual scene. Eye line of gaze is displayed on a scene monitor as a set of crosshairs superimposed on the image from this scene camera. The illuminator, optics and both cameras are all helmet mounted (see Figure 1). Video recordings of the subjects' eye line of gaze during the driving tests are used for determining their visual search for vehicles proceeding with right of way on the right at 58 intersections. The number of times a subject checked for traffic at intersections is taken as the dependent variable. 
Driving tests were conducted in a dual control, Volkswagen Golf stationwagon. Two persons accompanied the subject: a licensed driving instructor sitting in the front passenger seat and an assistant sitting in the center of the rear seat. The former had access to redundant controls and his primary responsibilities were controlling safety and rating the driver's performance retrospectively. The observer in the rear seat operated and monitored the eye tracking system. All subjects received a full dress-rehearsal of the driving test.

\subsection{Route recognition test}

This test consists of a series of 30 photographs displaying roadside views within the city of Maastricht, such as suburban and urban streets, main roads, signaled and unsignaled intersections and traffic circles. Separate photographs were shown for five seconds on a computer display in a successive fashion. Half of the time the photographs consisted of sites along the route of the City Driving Test, and half of the time of sites elsewhere. Subjects were required to indicate whether or not the photograph displayed a part of the route, by pressing corresponding buttons. The number of correct responses is taken as the dependent variable

\subsection{Questionnaires}

Prior to the driving test, subjects were asked for their willingness to drive in three different situations : a) unimportant though gratifying, such as transporting a friend to another party, b) important but avoidable, such as transporting a mildly sick friend home when he would otherwise have to call a taxi, c) urgent, such as transporting a severely sick child to the hospital. Visual-analog scales for measuring subjective feelings of intoxication ('high' and 'drunkenness') and mental effort while performing the test (Zijlsta \& Van Doorn, 1985) were administered at the onset and after the conclusion of the driving test. In addition, subjects 
were asked to rate retrospectively their perceived driving quality on a $10 \mathrm{~cm}$ visual analog scale. Mood was assessed using Bond and Lader's (1976) series of 16 visual-analog mood scales. The authors' procedures were followed for deriving three statistically independent scores for alertness, calmness and contentment.

\subsection{Statistical analysis}

Because most data did not pass requirements for conducting parametric statistics, as indicated by Mauchly sphericity tests, all variables measured on interval or ratio level were analyzed by means of non-parametric tests. Friedman tests were used for detecting an overall difference between treatments. These were followed by Wilcoxon's signed-rank tests to analyze each drug-placebo comparison separately. Willingness to drive data were analyzed for assessing differences between the three drug conditions and placebo condition using Cochran's Q-test. 


\section{RESULTS}

\subsection{Missing Data}

One subject did not complete mood, perceived driving quality and effort questionnaires during treatment with alcohol. Route recognition data of 3 subjects was lost due to technical malfunctioning.

\subsection{Intoxication}

Mean BACs at the onset of the driving test were practically identical after alcohol and alcohol combined with THC; i.e. about $0.042 \mathrm{~g} / \mathrm{dl}$. Rates of decline in BAC over the course of the driving tests were also comparable. Descriptive statistics of BACs are given in Table 3.

Table 3 Mean, median and range for BACs ( $g / d \mathrm{~d})$ measured in alcohol conditions before and after the driving test.

\begin{tabular}{lllll}
\hline & ALC & & ALC/THC & \\
\hline \multirow{2}{*}{ Mean } & before & after & before & after \\
Median & .042 & .036 & .041 & .034 \\
Range & $.041=$ & .034 & .040 & .034 \\
\hline
\end{tabular}

Perceived levels of drunkenness and high differed between treatments $\left(\chi^{2}>10.9 ; \mathrm{p}<\right.$ .012). Few subjects reported intoxication after placebo and their average levels were about $5 \%$ of maximum experience. After receiving THC or alcohol, mean intoxication levels rose to about $26 \%$ at the beginning of the driving test. At conclusion, intoxication levels declined to $10 \%$ in the alcohol condition but were virtually unchanged in the THC condition. Combined treatment with alcohol and THC produced similar levels of perceived high as in the THC 
condition, whereas mean levels of drunkenness were about $37 \%$ and thus slightly higher as compared to treatment with alcohol alone. Decline rates of intoxication levels after combined treatment were similar to those observed in the separate treatments. Wilcoxon rank tests showed that ratings of intoxication after active drugs were significantly different from placebo both before $(Z>-2.9 ; \mathrm{p}<.006)$ and after driving $(Z>2.5 ; \mathrm{p}<.001)$.

\subsection{Driving performance}

Means of all performance variables of the Driving Proficiency Test and the results from statistical analyses are given in Table 4. It is apparent that THC, alcohol as well as their combined use did not significantly affect the total score or any of the component scores.

Mean frequency of intersections searched for traffic was about $84 \%$ during placebo treatment. Treatment with alcohol or THC did not significantly affect the subjects' visual search frequency as compared to placebo. However, combined treatment with alcohol and THC reduced visual search frequency significantly, by about $3 \%(Z=-2.05 ; p=.041)$. Decline

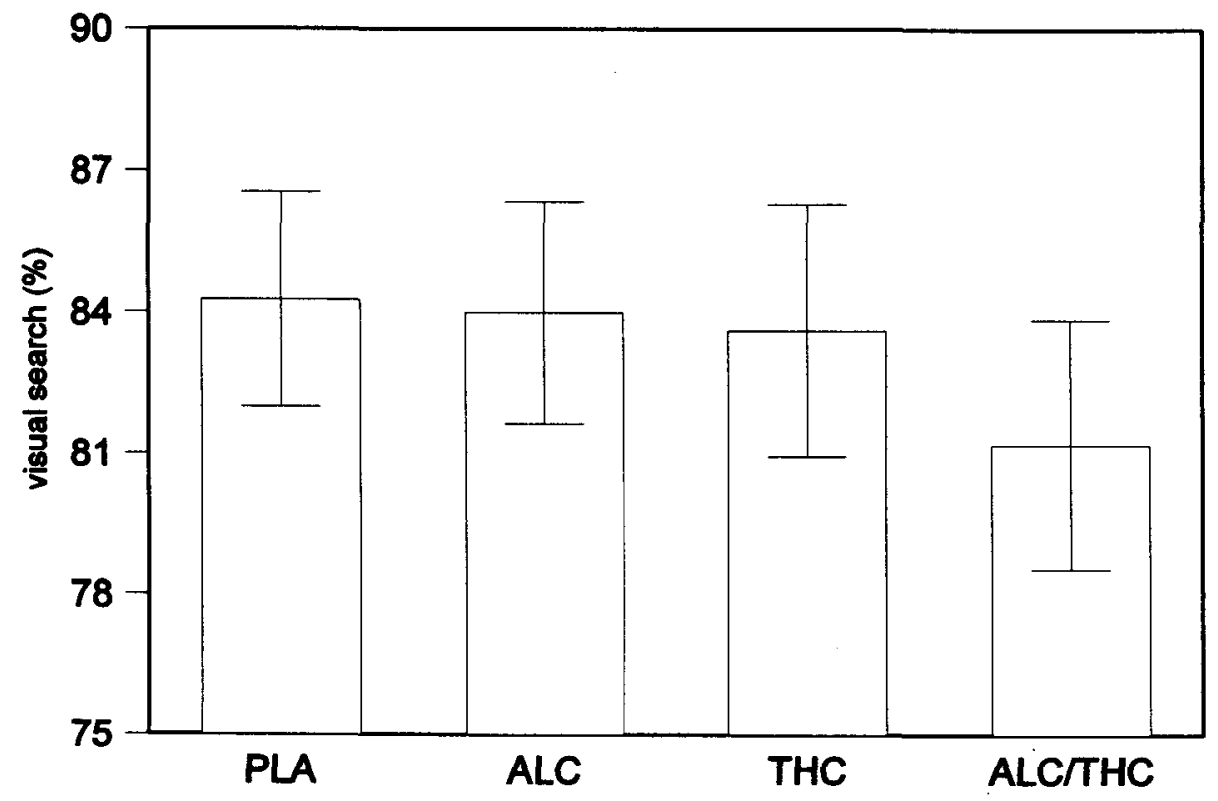

Figure 2 Mean (se) frequency of visual search for traffic at intersections in each treatment condition. 
in search frequency was most pronounced in female subjects (i.e. 7\%) but the effect of gender was only marginally significant $(\mathrm{p}=0.09)$. Mean $(\mathrm{SE})$ search frequencies at in each treatment condition are shown in Figure 2.

\subsection{Route recognition}

Mean frequency of sites along the driving course recalled by subjects at the conclusion of the driving tests are given in Table 4. Recognition was not affected by THC or THC combined with alcohol. Alcohol by itself significantly lowered the frequency of recall $(Z=-2.06$; $\mathrm{p}=0.04)$, as compared to the placebo.

\subsection{Questionnaires}

Mean (se) ratings of perceived driving performance and perceived effort are shown in Figures 3 and 4 respectively. The subjects' rating of driving performance was significantly lower in the THC condition as compared to those in the placebo condition $(\mathrm{Z}=-2.51 ; \mathrm{p}=0.012)$.

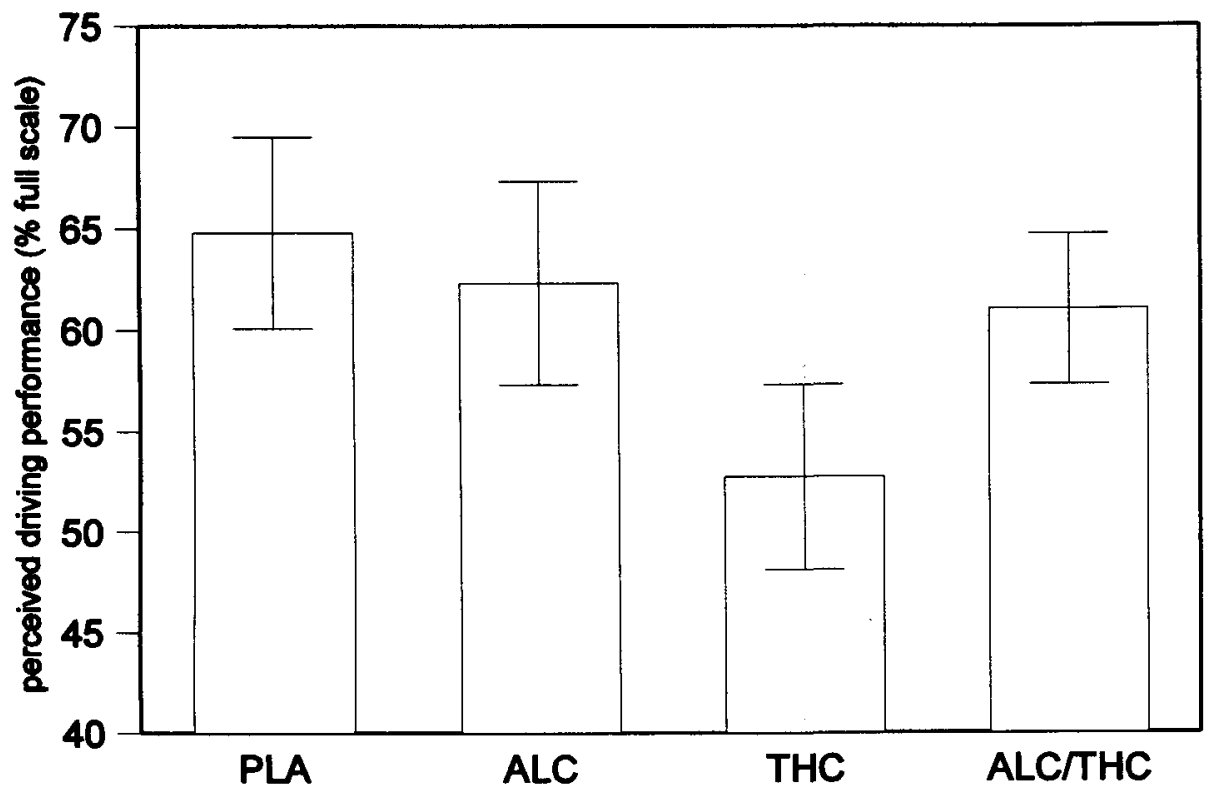

Figure 3 Mean (se) perceived driving performance in the City Driving Test by subjects in each treatment condition 
Subjects also perceived higher levels of effort to conduct the driving test in the THC condition, as compared to placebo treatment $(\mathrm{Z}=-2.327 ; \mathrm{p}=.020)$. Alcohol and alcohol combined with THC did not significantly alter the subjects ratings of driving quality and

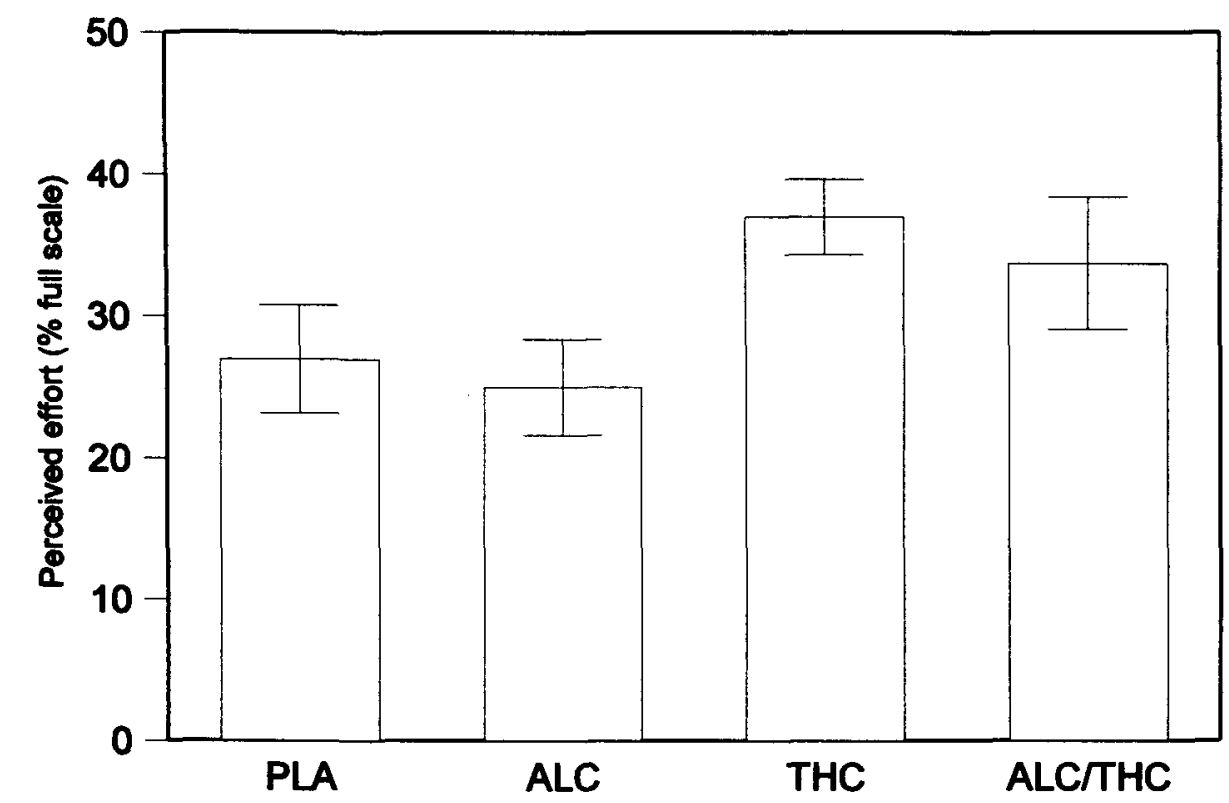

Figure 4 Mean (se) perceived effort to conduct the City Driving Test by subjects in each treatment condition.

effort.

The percentage of the subjects declaring they were willing to drive under different circumstances of a gradually more compelling nature (A. unimportant though gratifying; B. important but avoidable; C. urgent) are presented in Table 4. The more urgent the reason for driving, the more subjects declared they would be willing to drive. Treatment with THC or alcohol alone did not affect willingness to drive, although there were indications that THC and alcohol reduced the number of subjects willing to drive in unimportant conditions $(\mathrm{Q}=3.6$; $\mathrm{p}=0.58)$ and in important conditions $(\mathrm{Q}=3.57 ; \mathrm{p}=.059)$ respectively. Combined use of alcohol 
and THC significantly decreased the subjects' willingness to drive in any circumstance $(\mathrm{Q}>5.0 ; \mathrm{p}<.025)$.

Subjective ratings of alertness, contentness and calmness are shown in Table 4. Feelings of alertness were significantly diminished after treatment with THC $(Z=-2.43 ; p=.02)$ and after THC combined with alcohol $(\mathrm{Z}=-2.02 ; \mathrm{p}=.04)$. Relative to placebo, alertness declined

Table 4 Means (SE) of driving proficiency, route recognition and mood variables, and percentage of subjects willing to drive in each treatment condition. P-values indicate significant impairment as indicated by non-parametric statistics.

\begin{tabular}{|c|c|c|c|c|c|c|c|c|}
\hline \multirow[t]{3}{*}{ Tests } & \multicolumn{4}{|c|}{ Treatments } & \multicolumn{4}{|c|}{ Statistics } \\
\hline & \multirow[b]{2}{*}{ PLA } & \multirow[b]{2}{*}{ ALC } & \multirow[b]{2}{*}{ THC } & \multirow[b]{2}{*}{ ALC/THC } & \multirow{2}{*}{ Overall } & \multicolumn{3}{|c|}{ Comparisons vs PLA } \\
\hline & & & & & & ALC & THC & ALC/THC \\
\hline \multicolumn{5}{|c|}{ Driving proficiency Test } & & & & \\
\hline total score & $68.4(4.6)$ & $67.2(4.0)$ & $62.7(3.4)$ & $67.1(5.2)$ & - & - & - & - \\
\hline vehicle checks & $83.0(4.0)$ & $84.7(2.0)$ & $77.3(3.6)$ & $83.0(4.3)$ & - & - & - & - \\
\hline vehicle handling & $66.9(4.3)$ & $64.1(4.8)$ & $63.0(3.7)$ & $68.8(4.4)$ & - & - & - & - \\
\hline action in traffic & $68.9(5.1)$ & $65.9(4.4)$ & $63.8(4.1)$ & $63.4(6.0)$ & - & - & - & - \\
\hline observation traffic & $54.7(9.3)$ & $56.3(8.9)$ & $39.8(7.2)$ & $56.3(9.8)$ & - & - & - & - \\
\hline turning & $68.4(4.6)$ & $67.2(4.0)$ & $62.7(3.4)$ & $67.1(5.2)$ & - & - & - & - \\
\hline \multicolumn{9}{|c|}{ Route Recognition Test (\%) } \\
\hline items recalled & $80.0(2.5)$ & $75.1(2.6)$ & $77.4(3.4)$ & $76.4(3.3)$ & - & .04 & - & - \\
\hline \multicolumn{9}{|l|}{ Mood (\% full scale) } \\
\hline Alertness & $64.1(4.5)$ & $66.0(4.2)$ & $52.5(4.4)$ & $55.2(4.5)$ & .004 & - & .015 & .044 \\
\hline Contentment & $69.3(3.8)$ & $75.0(3.0)$ & $66.8(4.0)$ & $66.4(4.1)$ & - & - & - & - \\
\hline Calmness & $71.5(4.8)$ & $75.0(3.7)$ & $67.1(6.7)$ & $68.7(5.0)$ & - & - & - & - \\
\hline \multicolumn{9}{|c|}{ Willingness to drive (\% N) } \\
\hline A & 75 & 43.8 & 37.5 & 12.5 & .004 & - & - & .002 \\
\hline B & 87.5 & 56.3 & 62.5 & 25 & .003 & - & - & .002 \\
\hline $\mathrm{C}$ & 100 & 93.8 & 93.8 & 68.8 & .015 & - & - & .025 \\
\hline
\end{tabular}


by $18 \%$ in the THC condition and by $14 \%$ in THC/alcohol condition. Statistical tests revealed no significant treatment effects on contentment and calmness. 


\section{DISCUSSION}

The main objective of the present study was to measure the effects of a low dose of THC with and without a low dose of alcohol on driving proficiency of recreational users of marijuana and alcohol. Selected doses of THC and alcohol were comparable to those that produced practically no impairment in previous city driving studies (Klonoff, 1974; Robbe 1994). It was hypothesized that relatively low doses of THC and alcohol may still become hazardous to driving proficiency when taken together.

Results of the present study largely confirmed these expectations. According to the instructor's rating neither THC nor alcohol alone affected the subjects' driving performance. The subjects' visual search for traffic at intersections also remained unaffected in the presence of each drug given alone. The effects of alcohol on driving proficiency were even less then those seen after comparable doses in Robbe's study (1994). The latter reported that subjects' driving performance deteriorated slightly under the influence of alcohol. In particular, changes in 'handling of the vehicle' were significant. In both studies, mean BACs were about $0.04 \mathrm{~g} / \mathrm{dl}$ prior to the driving tests and the fall in plasma-alcohol concentrations during driving were about $0.006 \mathrm{~g} / \mathrm{dl}$. Subjects' perceptions of intoxication after administration of alcohol were also comparable in both studies; i.e. about $25 \%$ of maximal experience. Possibly, the presence or absence of a low-dose alcohol effect in these driving studies was influenced by variations in other, uncontrollable factors such as drug sensitivity, time of day or traffic condition. Their contribution to error variance may affect the sensitivity of tests for detecting a drug's action.

This is particularly true when the expected alcohol effect is very small, as in the present study.

The combined effects of alcohol and THC on the subjects' attention for other traffic during the driving test were potentially dangerous. Alcohol plus THC reduced the mean 
search frequency for traffic at intersections by about $3 \%$. The central driving task as measured by the instructor's rating of driving proficiency, was not affected by alcohol plus THC. Apparently, subjects were less able to detect peripheral traffic while trying to effectively perform the central driving task under the influence of alcohol and THC together. They were not able or chose not to divide their attention equally over both subtasks, but focussed on the central driving task instead. This corroborates results from previous simulator and laboratory studies that show adverse effects of THC and alcohol on subsidiary task performance (Moskowitz, 1973; Smiley, 1986; Ramaekers, 1996). In these studies, where peripheral search or recognition tasks were combined with a visual central tracking task, the greater error always occurred in the peripheral task. This is not due to a direct drug effect on the peripheral task itself, but is due to the focus on the central task. In the actual driving situation of the present study, for example, the constant demands for the ongoing central driving task may overshadow the intermittent demands of the peripheral search task, particularly in the presence of drugs.

In females, search frequency at intersections dropped with a remarkable $7 \%$ after alcohol plus THC. However, this apparent interaction between gender and treatment failed to reach statistical significance $(p=0.09)$. It is possible that females in the current sample may have been more sensitive to the drugs' effects. Inspection of demographic data shows that females were less experienced THC smokers than the males. On the average, the former group smoked about 3 THC cigarettes (range 2-8) per month, whereas the latter group consumed about 10 THC cigarettes (range 2-24) per month. The possibility, therefore, exists that males had driven more often under the influence of THC and developed more behavioral tolerance or task specific learning to compensate for the drugs' impairing influence on performance (Young and Goudie, 1994). 
There were other differences between the subjects' reactions to drugs and placebo. Subjects felt less alert and invested more effort in the test while driving under the influence of THC. They also rated their driving performance as being significantly worse after THC than placebo. In contrast, alcohol did not affect their subjective ratings of alertness, effort and driving proficiency. These results indicate that subjects were aware of the impairing properties of THC but not of alcohol. Consequently, they were more cautious during the driving test following THC. Previous on the road driving studies have also demonstrated that subjects are generally aware of the impairing properties of THC and try to compensate for the drugs' impairing properties by driving more carefully (Hansteen et al, 1976; Casswell, 1979; Peck et al, 1986, Robbe, 1994). However, subjects were no longer aware of the impairing properties of THC in the presence of alcohol. Their ratings of perceived driving proficiency and effort after combined use were similar than after placebo. It is of interest to note that feelings of drunkenness were stronger than feelings of high during the combined treatment. Levels of drunkenness rose by 12 percent, but levels of high did not change as compared to the drugs given alone. These findings support earlier notions that drivers become overconfident during drunkenness and more cautious and self-critical while in a state of high (Robbe, 1994). If so, the differences in driving performance observed during treatment with THC and THC in combination with alcohol might follow from the subjects' desire to compensate for detrimental effects in one condition but not in the other.

These impressions were somewhat contradicted by the subjects' responses indicating their willingness to drive after drugs and placebo. Between $12-25 \%$ of the subjects said they would have been willing to drive for less than urgent reasons after the combined use of THC and alcohol. The validity of willingness to drive ratings has been questioned because of the subjects desire to give socially desirable answers (Robbe, 1994). Indeed, all subjects in the 
present study admittedly had driven under the influence of marijuana, alcohol or their combination on previous occasions. At these times, impairment may also have been more severe, since perceived levels of intoxication in the current study were far below maximal experience.

Alcohol slightly decreased performance in the route recognition test, whereas THC did not. The latter effect is quite remarkable since one of the most consistently reported behavioral effects of marijuana is a disruption in the free recall of previously learned items. This effect is mediated by cannabinoid receptors located in the hippocampus that is involved in the control of short term memory functions. It is therefore believed that marijuana impairs acquisition and working memory but not the retrieval of information from long term memory (Ameri, 1999). From this point of view, it is important to note that subjects in the present study may have been familiar already with the route of the city driving test prior to the study. Most subjects had been living in the city for several years. Awareness of specific sites along the route thus could not be acquired only during the driving test, but may have resulted also from previous experience. That no effect of THC emerged in the memory test raises the suspicion that most subjects compensated for the THC effect on short term memory by retrieving pre-existing information from long term memory. 


\section{CONCLUSIONS}

- Low doses of marijuana (THC $100 \mu \mathrm{g} / \mathrm{kg}$ ) taken alone, did not impair city driving performance and did not diminish visual search frequency for traffic at intersections in this study.

- Low doses of alcohol sufficient for producing $\mathrm{BAC} \cong 0.04 \mathrm{~g} / \mathrm{dl}$ did not impair city driving performance and did not diminish visual search frequency for traffic at intersections in this study.

- Low doses of marijuana (THC $100 \mu \mathrm{g} / \mathrm{kg}$ ) in combination with alcohol sufficient for producing $\mathrm{BAC} \cong 0.04 \mathrm{~g} / \mathrm{dl}$ did not affect city driving proficiency, but did impair peripheral search for traffic in this study.

- The effects of low doses of marijuana (THC $100 \mu \mathrm{g} / \mathrm{kg}$ ) and alcohol sufficient for producing $\mathrm{BAC} \cong 0.04 \mathrm{~g} / \mathrm{dl}$ on city driving proficiency and visual search are minimal when taken alone, but potentially dangerous for traffic safety when combined. 
Ameri, A. (1999). The effects of cannabinoids on the brain. Progress in Neurobiology, 58(4)), 315-348.

Attwood, D. A., Williams, R. D., Bowser, J. S., McBurney, L. J., \& Frecker, R. C. (1981). The effects of moderate levels of alcohol and marijuana, alone and in combination on closed-course driving performance. ((81-RSU-17)). Downsview, Ontario: Defence and Civil Institute of Environmental Medicine.

Azorlosa, J. L., Heishman, S. J., Stitzer, M. L., \& Mahaffey, J. M. (1992). Marijuana smoking: effect of varying delta 9-tetrahydrocannabinol content and number of puffs. $J$ Pharmacol Exp Ther, 261(1), 114-22.

Barnett, G., Licko, V., \& Thompson, T. (1985). Behavioral pharmacokinetics of marijuana. Psychopharmacology Berl, 85(1), 51-6.

Bond, A. \& Lader, M (1974) The use of analogue scales in rating subjective feelings. $B r J$ Med Psychol, 47, 211-218

Budd, R. D., Muto, J. J., \& Wong, J. K. (1989). Drugs of abuse found in fatally injured drivers in Los Angeles County. Drug Alcohol Depend, 23(2), 153-8.

Casswell, S. (1979, 23-28 January). Cannabis and alcohol: Effects on closed course driving behaviour. Paper presented at the Seventh International Conference on Alcohol, Drugs and Traffic Safety. Proceedings., Melbourne 23-28 January 1977.

Chesher, G. B., \& Starmer, G. A. (1983). Cannabis and human performance skills (Grand Report Series ). Sydney, Australia, NSW: Drug and Alcohol Authority Research. 
Cimbura, G., Lucas, D. M., Bennett, R. C., Warren, R. A., \& Simpson, H. M. (1982). Incidence and toxicological aspects of drugs detected in 484 fatally injured drivers and pedestrians in Ontario. J Forensic Sci, 27(4), 855-67.

Cimbura, G., Warren, R. A., R.C., B., Lucas, D. M., \& Simpson, H. M. (1980). Drugs detected in fatally injured drivers and pedestrians in the province of Ontario. Ottawa: Traffic Injury Research Foundation of Canada.

Daldrup, T., Reudenbach, G., \& Kimm, K. (1987). [Cannabis and alcohol in traffic] Cannabis und Alkohol im Strassenverkehr. Blutalkohol, 24(2), 144-56.

De Gier, J. J. (1979). A subjective measurement of the influence of ethyl/alcohol in moderate doses on real driving performances. Blutalkohol, 16, 363-370.

De Gier, J. J., t Hart, B. J., Nelemans, F. A., \& Bergman, H. (1981). Psychomotor performance and real driving performance of outpatients receiving diazepam. Psychopharmacology Berl, 73(4), 340-4.

Donelson, A. C., Cimbura, G., Bennett, R. C., \& Lucas, D. M. (1985). The Ontario monitoring project: Cannabis and alcohol use among drivers and pedestrians fatally injured in motor vehicle accidents from March 1982 through July 1984. Ottawa, Canada: Traffic Injury Research Foundation of Canada.

Garriott, J. C., Di Maio, V. J., \& Rodriguez, R. G. (1986). Detection of cannabinoids in homicide victims and motor vehicle fatalities. J Forensic Sci, 31(4), 1274-82.

Hansteen, R. W., Miller, R. D., Lonero, L., Reid, L. D., \& Jones, B. (1976). Effects of cannabis and alcohol on automobile driving and psychomotor tracking. Ann N Y Acad Sci, 282, 240-56. 
Heishman, S. J., Stitzer, M. L., \& Yingling, J. E. (1989). Effects of tetrahydrocannabinol content on marijuana smoking behavior, subjective reports, and performance. Pharmacol Biochem Behav, 34(1), 173-9.

Klonoff, H. (1974). Marijuana and driving in real-life situations. Science, 186(4161), 317-324. Marks, D. F., \& MacAvoy; M. G. (1989). Divided attention performance in cannabis users and non-users following alcohol and cannabis separately and in combination. Psychopharmacology Berl, 99(3), 397-401.

McLean, S., Parsons, R. S., Chesterman, R. B., Dineen, R., Johnson, M. G., \& Davies, N. W. (1987). Drugs, alcohol and road accidents in Tasmania. Med J Aust, 147(1), 6-11.

Moskowitz, H. (1973). Laboratory studies of the effects of alcohol on some variables related to driving. Journal of Safety Research, 5(3), 185-199.

Moskowitz, H. (1985). Marihuana and driving. Accid Anal Prev, 17(4), 323-45.

Peck, R. C., Biasotti, A., Boland, P. N., Mallory, C., \& et al. (1986). The effects of marijuana and alcohol on actual driving performance. Alcohol, Drugs and Driving, 2(3-4), 135154.

Perez Reyes, M., Hicks, R. E., Bumberry, J., Jeffcoat, A. R., \& Cook, C. E. (1988). Interaction between marihuana and ethanol: effects on psychomotor performance. Alcohol Clin Exp Res, 12(2), 268-76.

Ramaekers, J. G., Muntjewerff, N. D., Uiterwijk, M. M. C., van Veggel, L. M. A., \& et al. (1996). A study of the pharmacodynamic interaction between befloxatone and ethanol on performance and mood in healthy volunteers. Journal of Psychopharmacology, 10(4), 288-294. 
Robbe HWJ, O’Hanlon JF (1999) Marijuana, alcohol and actual driving performance. DOT HS 808 939, National Highway Traffic Safety Administration, US department of Transportation, Washington D.C.

Robbe, H. (1998). Marijuana's impairing effects on driving are moderate when taken alone but severe when combined with alcohol. Human Psychopharmacology Clinical and Experimental, 13(Suppl 2), S70-S78.

Robbe, H. W. J. (1994). Influence of Marijuana on Driving. Maastricht: University of Limburg.

Smiley, A. (1986). Marijuana: On-road and driving simulator studies. Alcohol, Drugs and Driving, 2(3-4), 121-134.

Smiley, A. M. (1987). The effects of marijuana alone and in combinationa with alcohol on driving performance. Paper presented at the Proceedings of the 10th International Conference on Alcohol, Drugs and Traffic Safety, September 9-12, 1986, Amsterdam, The Netherlands.

Smiley, A. M., Moskowitz, H., \& Ziedman, K. (1981). Driving simulator studies of marijuana alone and in combination with alcohol. Paper presented at the Proceedings of the 25th Conference of the American Association for Automotive Medicine., ?

Soderstrom, C. A., Trifillis, A. L., Shankar, B. S., Clark, W. E., \& Cowley, R. A. (1988). Marijuana and alcohol use among 1023 trauma patients. A prospective study. Arch Surg, 123(6), 733-7.

Stein, A. C., Allen, R. W., Cook, M. L., \& Karl, R. L. (1983). A Simulator Study of the Combined Effects of Alcohol and Marijuana on Driving Behavior. (DOT HS 806 405). Hawthorne, CA: System Technology Inc. 
Terhune, K. W. (1982). The role of alcohol, marijuana and other drugs in the accidents of injured drivers. (Tech. Rep. under Contract No. DOT-HS-5-01179). Buffalo, New York: Calspan Field Services Inc.

Terhune KW, Ippolito CA, Hendriks DL, Michalovic JG (1992). The incidence and role of drugs in fatally injured drivers. National Highway Traffic Safety Administration. Final Report under Contract No. DTNH 22-88-C-07069.

Townsend, T. N., Lane, J., Dewa, S., \& Brittingham, A. M. (1998). Driving after drug or alcohol use: findings from the 1996 National Household Survey on Drug Abuse. DHHS 99-3273 SAMHSA, National Highway Traffic Safety Administration. US Department of Transportation, Washington DC.

Winer BJ (1962) Statistical principles in experimental design. McGraw-Hill, New York.

Williams, A. F., Peat, M. A., Crouch, D. J., Wells, J. K., \& Finkle, B. S. (1985). Drugs in fatally injured young male drivers. Public Health Rep, 100(1), 19-25.

Young, A. M., \& Goudie, A. J. (1994). Adaptive processes regulating tolerance to behavioral effects of drugs. In F. E. Bloom \& D. J. Kupfer (Eds.), Psychopharmacology: The fourth Generation of Progress. New York: Raven Press.

Zijlstra, F.R.H. \& Van Doorn L (1985) The construction of a scale to measure perceived effort. Technical report, University of Delft, Delft, The Netherlands. 


\section{APPENDIX A}

\section{Descriptives : Mean and individual data}


Table 1 Blood Alcohol Concentrations (g/d)

Time after ethanol administration: 1 H10 (before driving)

$\begin{array}{lllll}\text { SS } & \text { Pla } & \text { Alc } & \text { THC } & \text { Alc/THC } \\ 1 & & & & \\ 2 & 0.000 & 0.040 & 0.000 & 0.037 \\ 3 & 0.000 & 0.043 & 0.000 & 0.039 \\ 4 & 0.000 & 0.040 & 0.000 & 0.036 \\ 5 & 0.000 & 0.032 & 0.000 & 0.035 \\ 6 & 0.000 & 0.032 & 0.000 & 0.040 \\ 7 & 0.000 & 0.039 & 0.000 & 0.040 \\ 8 & 0.000 & 0.051 & 0.000 & 0.052 \\ 9 & 0.000 & 0.044 & 0.000 & 0.044 \\ 10 & 0.000 & 0.060 & 0.000 & 0.045 \\ 11 & 0.000 & 0.041 & 0.000 & 0.040 \\ 12 & 0.000 & 0.038 & 0.000 & 0.040 \\ 13 & 0.000 & 0.042 & 0.000 & 0.041 \\ 14 & 0.000 & 0.041 & 0.000 & 0.045 \\ 15 & 0.000 & 0.041 & 0.000 & 0.034 \\ 16 & 0.000 & 0.045 & 0.000 & 0.041 \\ & 0.000 & 0.048 & 0.000 & 0.040 \\ \text { Mean } & 0.000 & 0.042 & 0.000 & 0.040 \\ \text { StdDev } & 0.000 & 0.007 & 0.000 & 0.004 \\ \text { SE } & 0.000 & 0.002 & 0.000 & 0.001 \\ \text { Maximum } & 0.000 & 0.060 & 0.000 & 0.052 \\ \text { Minimum } & 0.000 & 0.032 & 0.000 & 0.034\end{array}$

Time after ethanol administration: 1 H50 (after driving)

$\begin{array}{lllll}\text { SS } & \text { Pla } & \text { Alc } & \text { THC } & \text { Alc/THC } \\ & & & & \\ 1 & 0.000 & 0.029 & 0.000 & 0.019 \\ 2 & 0.000 & 0.031 & 0.000 & 0.029 \\ 3 & 0.000 & 0.029 & 0.000 & 0.026 \\ 4 & 0.000 & 0.031 & 0.000 & 0.032 \\ 5 & 0.000 & 0.028 & 0.000 & 0.040 \\ 6 & 0.000 & 0.024 & 0.000 & 0.031 \\ 7 & 0.000 & 0.037 & 0.000 & 0.041 \\ 8 & 0.000 & 0.041 & 0.000 & 0.038 \\ 9 & 0.000 & 0.060 & 0.000 & 0.030 \\ 10 & 0.000 & 0.042 & 0.000 & 0.040 \\ 11 & 0.000 & 0.031 & 0.000 & 0.035 \\ 12 & 0.000 & 0.036 & 0.000 & 0.024 \\ 13 & 0.000 & 0.029 & 0.000 & 0.050 \\ 14 & 0.000 & 0.041 & 0.000 & 0.031 \\ 15 & 0.000 & 0.041 & 0.000 & 0.043 \\ 16 & 0.000 & 0.038 & 0,000 & 0,039 \\ & & & & \\ \text { Mean } & 0.000 & 0.036 & 0.000 & 0.034 \\ \text { StdDev } & 0.000 & 0.009 & 0.000 & 0.008 \\ \text { SE } & 0.000 & 0.002 & 0.000 & 0.002 \\ \text { Maximum } & 0.000 & 0.060 & 0.000 & 0.050 \\ \text { Minimum } & 0.000 & 0.024 & 0.000 & 0.019\end{array}$


Table 2 Feeling of being 'high' (\%)

Time after ethanol administration: 1 H10 (before driving)

\begin{tabular}{lrrrr} 
SS & \multicolumn{1}{c}{ Pla } & \multicolumn{1}{c}{ Alc } & THC & Alc/THC \\
& & & & \\
1 & 0.00 & 10.00 & 50.00 & 50.00 \\
2 & 0.00 & 0.00 & 26.00 & 65.00 \\
3 & 1.00 & 16.00 & 16.00 & 0.00 \\
4 & 1.00 & 0.00 & 24.00 & 0.00 \\
5 & 0.00 & 0.00 & 34.00 & 9.00 \\
6 & 5.00 & 3.00 & 4.00 & 26.00 \\
7 & 0.00 & 0.00 & 65.00 & 61.00 \\
8 & 0.00 & 70.00 & 30.00 & 14.00 \\
9 & 0.00 & 0.00 & 30.00 & 5.00 \\
10 & 18.00 & 6.00 & 2.00 & 6.00 \\
11 & 0.00 & 0.00 & 64.00 & 88.00 \\
12 & 19.00 & 7.00 & 2.00 & 20.00 \\
13 & 10.00 & 0.00 & 14.00 & 40.00 \\
14 & 0.00 & 0.00 & 60.00 & 50.00 \\
15 & 3.00 & 39.00 & 26.00 & 0.00 \\
16 & 20.00 & 1.00 & 23.00 & 42.00 \\
& & & & \\
Mean & 4.8 & 9.50 & 29.38 & 29.75 \\
StdDev & 7.53 & 19.02 & 20.82 & 27.46 \\
SE & 1.88 & 4.76 & 5.21 & 6.86 \\
Maximum & 20.00 & 70.00 & 65.00 & 88.00 \\
Minimum & 0.00 & 0.00 & 0.00 & 0.00
\end{tabular}

Time after ethanol administration: 1 H50 (after driving)

\begin{tabular}{lrrrr} 
SS & \multicolumn{1}{c}{ Pla } & \multicolumn{1}{c}{ Alc } & THC & Alc/THC \\
& & & & \\
1 & 0.00 & 0.00 & 20.00 & 40.00 \\
2 & 0.00 & 0.00 & 30.00 & 44.00 \\
3 & 0.00 & 21.00 & 35.00 & 2.00 \\
4 & 1.00 & & 26.00 & 0.00 \\
5 & 0.00 & 0.00 & 20.00 & 2.00 \\
6 & 33.00 & 2.00 & 4.00 & 54.00 \\
7 & 0.00 & 0.00 & 65.00 & 60.00 \\
8 & 0.00 & 0.00 & 0.00 & 70.00 \\
9 & 0.00 & 1.00 & 14.00 & 3.00 \\
10 & 35.00 & 2.00 & 26.00 & 5.00 \\
11 & 0.00 & 0.00 & 50.00 & 35.00 \\
12 & 18.00 & 7.00 & 3.00 & 20.00 \\
13 & 2.00 & 0.00 & 20.00 & 10.00 \\
14 & 0.00 & 0.00 & 70.00 & 40.00 \\
15 & 5.00 & 29.00 & 29.00 & 0.00 \\
16 & 24.00 & 1.00 & 32.00 & 63.00 \\
& & & & \\
Mean & 7.38 & 4.20 & 27.75 & 28.00 \\
StdDev & 12.58 & 8.77 & 20.11 & 25.49 \\
SE & 3.14 & 2.26 & 5.03 & 6.37 \\
Maximum & 35.00 & 29.00 & 70.00 & 70.00 \\
Minimum & 0.00 & 0.00 & 0.00 & 0.00
\end{tabular}


Table 3 Feeling of drunkenness (\%)

Time after ethanol administration: 1 H10 (before driving)

\begin{tabular}{lrrrr} 
SS & \multicolumn{1}{c}{ Pla } & \multicolumn{1}{c}{ Alc } & THC & Alc/THC \\
& & & & \\
1 & 0.00 & 40.00 & 0.00 & 51.00 \\
2 & 0.00 & 15.00 & 0.00 & 16.00 \\
3 & 0.00 & 24.00 & 0.00 & 22.00 \\
4 & 0.00 & 5.00 & 0.00 & 30.00 \\
5 & 0.00 & 4.00 & 0.00 & 5.00 \\
6 & 0.00 & 34.00 & 2.00 & 55.00 \\
7 & 20.00 & 40.00 & 5.00 & 29.00 \\
8 & 0.00 & 41.00 & 0.00 & 70.00 \\
9 & 0.00 & 10.00 & 20.00 & 0.00 \\
10 & 5.00 & 26.00 & 2.00 & 34.00 \\
11 & 0.00 & 10.00 & 0.00 & 54.00 \\
12 & 9.00 & 9.00 & 2.00 & 9.00 \\
13 & 1.00 & 20.00 & 0.00 & 40.00 \\
14 & 0.00 & 39.00 & 0.00 & 60.00 \\
15 & 2.00 & 30.00 & 1.00 & 49.00 \\
16 & 0.00 & 27.00 & 0.00 & 58.00 \\
& & & & \\
Mean & 2.31 & 23.38 & 2.00 & 36.38 \\
StdDev & 5.33 & 13.28 & 4.99 & 21.57 \\
SE & 1.33 & 3.32 & 1.25 & 5.39 \\
Maximum & 20.00 & 41.00 & 20.00 & 70.00 \\
Minimum & 0.00 & 4.00 & 0.00 & 0.00
\end{tabular}

Time after ethanol administration: 1 H50 (after driving)

\begin{tabular}{lrrrr} 
SS & Pla & \multicolumn{1}{c}{ Alc } & THC & Alc/THC \\
1 & & & & \\
2 & 0.00 & 10.00 & 0.00 & 19.00 \\
3 & 0.00 & 5.00 & 0.00 & 15.00 \\
4 & 0.00 & 7.00 & 0.00 & 20.00 \\
5 & 0.00 & & 0.00 & 21.00 \\
6 & 0.00 & 5.00 & 0.00 & 7.00 \\
7 & 0.00 & 34.00 & 3.00 & 45.00 \\
8 & 20.00 & 39.00 & 5.00 & 30.00 \\
9 & 0.00 & 0.00 & 0.00 & 40.00 \\
10 & 0.00 & 1.00 & 6.00 & 0.00 \\
11 & 8.00 & 29.00 & 1.00 & 33.00 \\
12 & 0.00 & 10.00 & 0.00 & 53.00 \\
13 & 9.00 & 9.00 & 4.00 & 9.00 \\
14 & 0.00 & 4.00 & 0.00 & 12.00 \\
15 & 1.00 & 30.00 & 0.00 & 51.00 \\
16 & 5.00 & 30.00 & 1.00 & 65.00 \\
& 10.00 & 18.00 & 0.00 & 20.00 \\
Mean & 3.31 & 15.40 & 1.25 & 27.50 \\
StdDev & 5.75 & 13.31 & 2.05 & 18.71 \\
SE & 1.44 & 3.44 & 0.51 & 4.68 \\
Maximum & 20.00 & 39.00 & 6.00 & 65.00 \\
Minimum & 0.00 & 0.00 & 0.00 & 0.00
\end{tabular}


Table 4 Royal Dutch Tourist Association's Driving Proficiency Test (\% correct)

Total score

\begin{tabular}{lrrrr} 
SS & \multicolumn{1}{l}{ Pla } & Alc & THC & Alc/THC \\
1 & & & & \\
2 & 82.22 & 77.78 & 62.22 & 72.22 \\
3 & 37.78 & 32.22 & 35.56 & 25.56 \\
4 & 45.56 & 51.11 & 48.89 & 71.11 \\
5 & 35.56 & 70.00 & 44.44 & 41.11 \\
6 & 85.56 & 74.44 & 73.33 & 92.22 \\
7 & 93.33 & 91.11 & 88.89 & 84.44 \\
8 & 66.67 & 64.44 & 53.33 & 71.11 \\
9 & 75.56 & 45.56 & 68.89 & 85.56 \\
10 & 67.78 & 55.56 & 61.11 & 75.56 \\
11 & 73.33 & 67.78 & 58.89 & 55.56 \\
12 & 68.89 & 75.56 & 68.89 & 75.56 \\
13 & 81.11 & 83.33 & 85.56 & 77.78 \\
14 & 43.33 & 76.67 & 65.56 & 33.33 \\
15 & 92.22 & 86.67 & 63.33 & 88.89 \\
16 & 70.00 & 55.56 & 56.67 & 44.44 \\
& 75.56 & 66.67 & 67.78 & 78.89 \\
Mean & 68.40 & 67.15 & 62.71 & 67.08 \\
StdDev & 18.50 & 15.86 & 13.75 & 20.64 \\
SE & 4.63 & 3.96 & 3.44 & 5.16 \\
Maximum & 93.33 & 91.11 & 88.89 & 92.22 \\
Minimum & 35.56 & 32.22 & 35.56 & 25.56
\end{tabular}

Subscore: vehicle checks

\begin{tabular}{lrrrr} 
SS & \multicolumn{1}{l}{ Pla } & \multicolumn{1}{l}{ Alc } & \multicolumn{1}{l}{ THC } & Alc/THC \\
1 & & & & \\
2 & 81.82 & 90.91 & 63.64 & 72.73 \\
3 & 54.55 & 81.82 & 54.55 & 45.45 \\
4 & 72.73 & 90.91 & 72.73 & 81.82 \\
5 & 54.55 & 90.91 & 72.73 & 72.73 \\
6 & 90.91 & 72.73 & 90.91 & 100.00 \\
7 & 100.00 & 100.00 & 100.00 & 100.00 \\
8 & 72.23 & 81.82 & 72.73 & 81.82 \\
9 & 100.00 & 72.73 & 72.73 & 100.00 \\
10 & 81.82 & 81.82 & 90.91 & 81.82 \\
11 & 81.82 & 81.82 & 63.64 & 54.55 \\
12 & 90.91 & 90.91 & 81.82 & 100.00 \\
13 & 81.82 & 81.82 & 72.73 & 100.00 \\
14 & 63.64 & 81.82 & 90.91 & 72.73 \\
15 & 100.00 & 90.91 & 54.55 & 100.00 \\
16 & 100.00 & 72.73 & 81.82 & 72.73 \\
& 100.00 & 90.91 & 100.00 & 90.91 \\
Mean & 82.95 & 84.66 & 77.27 & 82.95 \\
StdDev & 15.88 & 7.94 & 14.47 & 17.21 \\
SE & 3.97 & 1.98 & 3.62 & 4.30 \\
Maximum & 100.00 & 100.00 & 100.00 & 100.00 \\
Minimum & 54.55 & 72.73 & 54.55 & 45.45
\end{tabular}


Table 4 (continued)

Subscore: vehicle handling

\begin{tabular}{lrrrr} 
SS & \multicolumn{1}{l}{ Pla } & Alc & THC & Alc/THC \\
1 & & & & \\
2 & 83.33 & 66.67 & 75.00 & 75.00 \\
3 & 41.67 & 29.17 & 41.67 & 29.17 \\
4 & 50.00 & 37.50 & 50.00 & 79.17 \\
5 & 33.33 & 66.67 & 50.00 & 58.33 \\
6 & 75.00 & 75.00 & 79.17 & 83.33 \\
7 & 87.50 & 83.33 & 79.17 & 83.33 \\
8 & 70.83 & 70.83 & 50.00 & 62.50 \\
9 & 66.67 & 33.33 & 58.33 & 79.17 \\
10 & 70.83 & 37.50 & 45.83 & 75.00 \\
11 & 75.00 & 75.00 & 75.00 & 66.67 \\
12 & 62.50 & 79.17 & 70.83 & 79.17 \\
13 & 87.50 & 87.50 & 87.50 & 75.00 \\
14 & 45.83 & 70.83 & 45.83 & 41.67 \\
15 & 87.50 & 87.50 & 75.00 & 83.33 \\
16 & 75.00 & 62.50 & 54.17 & 41.67 \\
& 58.33 & 62.50 & 70.83 & 87.50 \\
Mean & 66.93 & 64.06 & 63.02 & 68.75 \\
StdDev & 17.04 & 19.36 & 14.90 & 17.55 \\
SE & 4.26 & 4.84 & 3.72 & 4.39 \\
Maximum & 87.50 & 87.50 & 87.50 & 87.50 \\
Minimum & 33.33 & 29.17 & 41.67 & 29.17
\end{tabular}

Subscore: traffic manoeuvres

\begin{tabular}{lrrrr} 
SS & \multicolumn{1}{l}{ Pla } & \multicolumn{1}{l}{ Alc } & THC & Alc/THC \\
& & & & \\
1 & 80.95 & 80.95 & 54.76 & 69.05 \\
2 & 30.95 & 21.43 & 26.19 & 19.05 \\
3 & 42.86 & 52.38 & 52.38 & 57.14 \\
4 & 33.33 & 66.67 & 42.86 & 28.57 \\
5 & 88.10 & 78.57 & 73.81 & 95.24 \\
6 & 95.24 & 90.48 & 92.86 & 88.10 \\
7 & 69.05 & 59.52 & 59.52 & 71.43 \\
8 & 78.57 & 45.24 & 73.81 & 83.33 \\
9 & 64.29 & 54.76 & 66.67 & 71.43 \\
10 & 78.57 & 66.67 & 52.38 & 54.76 \\
11 & 71.43 & 78.57 & 71.43 & 78.57 \\
12 & 71.43 & 76.19 & 88.10 & 76.19 \\
13 & 47.62 & 78.57 & 73.81 & 21.43 \\
14 & 92.86 & 83.33 & 66.67 & 85.71 \\
15 & 66.67 & 54.76 & 61.90 & 42.86 \\
16 & 90.48 & 66.67 & 64.29 & 71.43 \\
& & & & \\
Mean & 68.90 & 65.92 & 63.84 & 63.39 \\
StdDev & 20.51 & 17.51 & 16.39 & 23.97 \\
SE & 5.13 & 4.38 & 4.10 & 5.99 \\
Maximum & 95.24 & 90.48 & 92.86 & 95.24 \\
Minimum & 30.95 & 21.43 & 26.19 & 19.05
\end{tabular}


Table 4 (continued)

Subscore: observation and understanding traffic

\begin{tabular}{lrrrr} 
SS & \multicolumn{1}{l}{ Pla } & \multicolumn{1}{c}{ Alc } & \multicolumn{1}{l}{ THC } & Alc/THC \\
& & & & \\
1 & 100.00 & 75.00 & 75.00 & 62.50 \\
2 & 12.50 & .00 & .00 & .00 \\
3 & 12.50 & 37.50 & 12.50 & 87.50 \\
4 & 25.00 & 87.50 & 12.50 & .00 \\
5 & 100.00 & 87.50 & 37.50 & 100.00 \\
6 & 100.00 & 100.00 & 75.00 & 37.50 \\
7 & 50.00 & 25.00 & 25.00 & 100.00 \\
8 & 87.50 & 25.00 & 62.50 & 87.50 \\
9 & 50.00 & 75.00 & 50.00 & 87.50 \\
10 & 25.00 & 12.50 & 25.00 & 37.50 \\
11 & 25.00 & 37.50 & 25.00 & 37.50 \\
12 & 100.00 & 100.00 & 100.00 & 50.00 \\
13 & .00 & 100.00 & 50.00 & 12.50 \\
14 & 100.00 & 87.50 & 12.50 & 100.00 \\
15 & 50.00 & 25.00 & 12.50 & .00 \\
16 & 37.50 & 25.00 & 62.50 & 100.00 \\
& & & & \\
Mean & 54.69 & 56.25 & 39.84 & 56.25 \\
StdDev & 37.33 & 35.65 & 28.95 & 39.26 \\
SE & 9.33 & 8.91 & 7.24 & 9.82 \\
Maximum & 100.00 & 100.00 & 100.00 & 100.00 \\
Minimum & .00 & .00 & .00 & .00
\end{tabular}

Subscore: turning

\begin{tabular}{lrrrr} 
SS & \multicolumn{1}{l}{ Pla } & \multicolumn{1}{c}{ Alc } & \multicolumn{1}{c}{ THC } & Alc/THC \\
1 & 60.00 & 80.00 & 40.00 & 40.00 \\
2 & 80.00 & 80.00 & 100.00 & 100.00 \\
3 & 40.00 & 40.00 & 20.00 & 20.00 \\
4 & 40.00 & 40.00 & 20.00 & 20.00 \\
5 & 80.00 & 20.00 & 60.00 & 60.00 \\
6 & 80.00 & 100.00 & 100.00 & 100.00 \\
7 & 40.00 & 100.00 & 20.00 & 20.00 \\
8 & 20.00 & 80.00 & 80.00 & 80.00 \\
9 & 80.00 & 60.00 & 40.00 & 40.00 \\
10 & 80.00 & 100.00 & 80.00 & 80.00 \\
11 & 100.00 & 60.00 & 80.00 & 80.00 \\
12 & 100.00 & 100.00 & 60.00 & 60.00 \\
13 & 20.00 & 40.00 & 60.00 & 60.00 \\
14 & 80.00 & 100.00 & 80.00 & 80.00 \\
15 & 40.00 & 40.00 & 40.00 & 40.00 \\
16 & 40.00 & 100.00 & 20.00 & 20.00 \\
& & & & \\
Mean & 61.25 & 71.25 & 56.25 & 72.50 \\
StdDev & 26.80 & 28.25 & 28.49 & 26.20 \\
SE & 6.70 & 7.06 & 7.12 & 6.55 \\
Maximum & 100.00 & 100.00 & 100.00 & 100.00 \\
Minimum & .00 & .00 & .00 & .00
\end{tabular}


Table 5 Visual search frequency for traffic at intersections (\%)

\begin{tabular}{lrrrrl} 
SS & \multicolumn{1}{l}{ Pla } & \multicolumn{1}{l}{ Alc } & THC & Alc/THC & Gender (F=female/M=male) \\
& & & & & \\
1 & 75.00 & 71.55 & 68.10 & 74.14 & $\mathrm{~F}$ \\
2 & 77.59 & 81.03 & 86.21 & 93.10 & $\mathrm{M}$ \\
3 & 85.34 & 87.93 & $\mathbf{9 4 . 8 3}$ & 75.86 & $\mathrm{M}$ \\
4 & 79.31 & 81.90 & 90.52 & 80.17 & $\mathrm{M}$ \\
5 & 87.93 & 85.34 & 85.34 & 87.93 & $\mathrm{~F}$ \\
6 & 92.24 & 95.69 & 89.66 & 87.93 & $\mathrm{~F}$ \\
7 & 84.48 & 81.03 & 79.31 & 88.79 & $\mathrm{M}$ \\
8 & 75.86 & 79.31 & 80.71 & 74.14 & $\mathrm{M}$ \\
9 & 89.66 & 88.79 & 96.55 & 86.21 & $\mathrm{M}$ \\
10 & 89.66 & 75.00 & 75.86 & 64.66 & $\mathrm{~F}$ \\
11 & 63.79 & 65.52 & 58.62 & 56.90 & $\mathrm{~F}$ \\
12 & 86.21 & 81.03 & 85.34 & 83.62 & $\mathrm{~F}$ \\
13 & 75.00 & 79.31 & 71.55 & 73.28 & $\mathrm{M}$ \\
14 & 93.10 & 95.69 & 92.24 & 87.07 & $\mathrm{~F}$ \\
15 & 96.55 & 96.55 & 94.83 & 90.52 & $\mathrm{~F}$ \\
16 & 96.55 & 98.28 & 88.79 & 94.83 & $\mathrm{M}$ \\
& & & & & \\
Mean & 84.27 & 84.00 & 83.62 & 81.20 & \\
StdDev & 9.13 & 9.41 & 10.70 & 10.60 & \\
SE & 2.28 & 2.35 & 2.68 & 2.65 & \\
Maximum & 96.55 & 98.28 & 96.55 & 94.83 & \\
Minimum & 63.79 & 65.52 & 58.62 & 56.90 &
\end{tabular}

Males

$\begin{array}{lrrrr}\text { Mean } & \mathbf{8 2 . 9 7} & \mathbf{8 4 . 7 0} & 85.99 & 83.30 \\ \text { StdDev } & 7.50 & 6.59 & 8.49 & 8.60 \\ \text { SE } & 2.65 & 2.33 & 3.00 & 3.04 \\ \text { Maximum } & 96.55 & 98.28 & 96.55 & 94.83 \\ \text { Minimum } & 75.00 & 79.31 & 71.55 & 73.28\end{array}$

Females

$\begin{array}{lrrrr}\text { Mean } & 85.56 & 83.30 & 81.25 & 79.09 \\ \text { StdDev } & 10.89 & 12.04 & 12.67 & 12.52 \\ \text { SE } & 3.85 & 4.26 & 4.48 & 4.43 \\ \text { Maximum } & 96.55 & 96.55 & 94.83 & 90.52 \\ \text { Minimum } & 63.79 & 65.52 & 58.62 & 56.90\end{array}$


Table 6 Route Recognition Test (\% correct)

$\begin{array}{lcccc}\text { SS } & \text { Pla } & \text { Alc } & \text { THC } & \text { Alc/THC } \\ 1 & & & & \\ 2 & 93,33 & 90,00 & 76,67 & 63,33 \\ 3 & 63,33 & 63,33 & 53,33 & 56,67 \\ 4 & 73,33 & 70,00 & 70,00 & 73,33 \\ 5 & 76,67 & 76,67 & 86,67 & 73,33 \\ 6 & 76,67 & 80,00 & 76,67 & 90,00 \\ 7 & 80,00 & 70,00 & 76,67 & 83,33 \\ 8 & 76,67 & 83,33 & 83,33 & 80,00 \\ 9 & 93,33 & 76,67 & 86,67 & 93,33 \\ 10 & 80,00 & 63,33 & 70,00 & 76,67 \\ 11 & 73,33 & 70,00 & 80,00 & 66,67 \\ 15 & 90,00 & 80,00 & 86,67 & 73,33 \\ 16 & 73,33 & 63,33 & 60,00 & 66,67 \\ & 90,00 & 90,00 & 100,00 & 96,67 \\ \text { Mean } & 80.00 & 75.13 & & \\ \text { StdDev } & 9.13 & 9.39 & 12.44 & 76.41 \\ \text { SE } & 2.53 & 2.60 & 3.40 & 11.98 \\ \text { Maximum } & 93.33 & 90.00 & 100.00 & 96.32 \\ \text { Minimum } & 63.33 & 63.33 & 53.33 & 56.67\end{array}$

Table 7 Perceived effort (\% full scale)

\begin{tabular}{lrrrr} 
SS & \multicolumn{1}{c}{ Pla } & \multicolumn{1}{c}{ Alc } & THC & Alc/THC \\
1 & & & & \\
2 & 56.00 & 24.00 & 47.33 & 68.00 \\
3 & 22.67 & 14.00 & 47.33 & 30.00 \\
4 & 38.67 & 52.00 & 46.67 & 26.00 \\
5 & 10.00 & & 24.00 & 34.67 \\
6 & 5.33 & 29.33 & 46.67 & 14.00 \\
7 & 42.67 & 11.33 & 45.33 & 14.67 \\
8 & 37.33 & 36.00 & 48.00 & 47.33 \\
9 & 21.33 & 47.33 & 18.67 & 35.33 \\
10 & 28.00 & 30.00 & 39.33 & 24.00 \\
11 & 39.33 & 16.00 & 20.00 & 46.00 \\
12 & 15.33 & 31.33 & 31.33 & 22.00 \\
13 & 10.00 & 12.00 & 26.67 & 13.33 \\
14 & 40.00 & 19.33 & 46.00 & 52.67 \\
15 & 17.33 & 12.00 & 40.00 & 30.67 \\
16 & 8.67 & 30.67 & 29.33 & 70.00 \\
& 38.67 & 9.33 & 34.67 & 10.00 \\
Mean & 26.96 & 24.98 & 36.96 & 33.67 \\
StdDev & 15.17 & 13.28 & 10.59 & 18.68 \\
SE & 3.79 & 3.43 & 2.65 & 4.67 \\
Maximum & 56.00 & 52.00 & 48.00 & 70.00 \\
Minimum & 5.33 & 9.33 & 18.67 & 10.00
\end{tabular}


Table 8 Perceived driving quality (\% full scale)

\begin{tabular}{lrrrr} 
SS & \multicolumn{1}{l}{ Pla } & Alc & THC & Alc/THC \\
& & & & \\
1 & 51.00 & 61.00 & 52.00 & 28.00 \\
2 & 65.00 & 86.00 & 32.00 & 68.00 \\
3 & 75.00 & 25.00 & 74.00 & 61.00 \\
4 & 70.00 & & 52.00 & 70.00 \\
5 & 69.00 & 64.00 & 70.00 & 78.00 \\
6 & 74.00 & 70.00 & 62.00 & 57.00 \\
7 & 23.00 & 22.00 & 35.00 & 45.00 \\
8 & 92.00 & 89.00 & 89.00 & 74.00 \\
9 & 64.00 & 56.00 & 61.00 & 60.00 \\
10 & 73.00 & 67.00 & 41.00 & 48.00 \\
11 & 49.00 & 51.00 & 41.00 & 49.00 \\
12 & 81.00 & 84.00 & 74.00 & 74.00 \\
13 & 84.00 & 63.00 & 64.00 & 82.00 \\
14 & 50.00 & 72.00 & 29.00 & 57.00 \\
15 & 82.00 & 67.00 & 29.00 &. \\
16 & 34.00 & 58.00 & 38.00 & 64.00 \\
& & & & \\
Mean & 64.75 & 62.33 & 52.69 & 61.00 \\
StdDev & 18.84 & 19.18 & 18.55 & 14.39 \\
SE & 4.71 & 4.95 & 4.64 & 3.71 \\
Maximum & 92.00 & 89.00 & 89.00 & 82.00 \\
Minimum & 23.00 & 22.00 & 29.00 & 28.00
\end{tabular}

Table 9 Willingness to drive $(1=y e s, 0=$ no $)$

Circumstance $A$ : unimportant though gratifying

$\begin{array}{lllll}\text { SS } & \text { Pla } & \text { Alc } & \text { THC } & \text { Alc/THC } \\ 1 & 1 & 0 & 0 & 0 \\ 2 & 1 & 0 & 0 & 0 \\ 3 & 1 & 1 & 1 & 1 \\ 4 & 1 & 1 & 1 & 1 \\ 5 & 1 & 1 & 0 & 0 \\ 6 & 0 & 0 & 1 & 0 \\ 7 & 1 & 1 & 0 & 0 \\ 8 & 1 & 0 & 1 & 0 \\ 9 & 1 & 0 & 0 & 0 \\ 10 & 0 & 1 & 1 & 0 \\ 11 & 1 & 0 & 0 & 0 \\ 12 & 0 & 0 & 0 & 0 \\ 13 & 1 & 0 & 1 & 0 \\ 14 & 1 & 1 & 0 & 0 \\ 15 & 1 & 0 & 0 & 0 \\ 16 & 0 & 1 & 0 & 0 \\ & & & & \\ \text { Total } & 12 & 7 & 6 & 2\end{array}$


Table 9 (continued)

Circumstance B : important but avoidable

$\begin{array}{lllll}\text { SS } & \text { Pla } & \text { Alc } & \text { THC } & \text { Alc/THC } \\ 1 & 1 & 0 & 1 & 0 \\ 2 & 1 & 0 & 0 & 0 \\ 3 & 1 & 1 & 1 & 1 \\ 4 & 1 & 1 & 1 & 1 \\ 5 & 1 & 1 & 0 & 1 \\ 6 & 1 & 0 & 1 & 0 \\ 7 & 0 & 1 & 1 & 0 \\ 8 & 1 & 0 & 1 & 0 \\ 9 & 1 & 1 & 0 & 1 \\ 10 & 1 & 1 & 1 & 0 \\ 11 & 1 & 0 & 0 & 0 \\ 12 & 0 & 0 & 0 & 0 \\ 13 & 1 & 1 & 1 & 0 \\ 14 & 1 & 1 & 1 & 0 \\ 15 & 1 & 0 & 0 & 0 \\ 16 & 1 & 1 & 1 & 0 \\ & & & & \\ \text { Total } & 14 & 9 & 10 & 4\end{array}$

Circumstance $C$ : urgent

$\begin{array}{lllll}\text { SS } & \text { Pla } & \text { Alc } & \text { THC } & \text { Alc/THC } \\ 1 & 1 & 1 & 1 & 1 \\ 2 & 1 & 1 & 1 & 1 \\ 3 & 1 & 1 & 1 & 1 \\ 4 & 1 & 1 & 1 & 1 \\ 5 & 1 & 1 & 1 & 1 \\ 6 & 1 & 1 & 1 & 0 \\ 7 & 1 & 1 & 1 & 1 \\ 8 & 1 & 1 & 1 & 0 \\ 9 & 1 & 1 & 1 & 1 \\ 10 & 1 & 1 & 1 & 1 \\ 11 & 1 & 1 & 0 & 0 \\ 12 & 1 & 1 & 1 & 1 \\ 13 & 1 & 1 & 1 & 1 \\ 14 & 1 & 1 & 1 & 1 \\ 15 & 1 & 0 & 1 & 0 \\ 16 & 1 & 1 & 1 & 0\end{array}$

$\begin{array}{lllll}\text { Total } & 16 & 15 & 15 & 11\end{array}$ 
Table 10 Bond and lader: Mood (\% full scale)

\begin{tabular}{lrrrr} 
Alertness & \multicolumn{5}{l}{} \\
SS & Pla & Alc & THC & Alc/THC \\
& & & & \\
1 & 53.00 & 67.00 & 39.00 & 47.00 \\
2 & 78.00 & 89.00 & 51.00 & 77.00 \\
3 & 69.00 & 39.00 & 51.00 & 52.00 \\
4 & 80.00 & & 61.00 & 68.00 \\
5 & 72.00 & 73.00 & 61.00 & 70.00 \\
6 & 49.00 & 50.00 & 70.00 & 34.00 \\
7 & 48.00 & 49.00 & 36.00 & 38.00 \\
8 & 93.00 & 88.00 & 96.00 & 71.00 \\
9 & 85.00 & 85.00 & 61.00 & 79.00 \\
10 & 39.00 & 58.00 & 36.00 & 32.00 \\
11 & 40.00 & 77.00 & 42.00 & 50.00 \\
12 & 73.00 & 84.00 & 76.00 & 77.00 \\
13 & 55.00 & 65.00 & 47.00 & 64.00 \\
14 & 67.00 & 67.00 & 46.00 & 50.00 \\
15 & 85.00 & 52.00 & 32.00 & 21.00 \\
16 & 40.00 & 47.00 & 33.00 & 52.00 \\
& & & & \\
Mean & 64.09 & 66.00 & 52.47 & 55.17 \\
StdDev & 17.93 & 16.31 & 17.66 & 18.03 \\
SE & 4.48 & 4.21 & 4.42 & 4.51 \\
Maximum & 93.00 & 89.00 & 96.00 & 79.00 \\
Minimum & 39.00 & 39.00 & 32.00 & 21.00
\end{tabular}

\section{Calmness}

$\begin{array}{lrrrr}\text { SS } & \text { Pla } & \text { Alc } & \text { THC } & \text { Alc/THC } \\ & & & & \\ 1 & 48.00 & 61.00 & 78.00 & 25.00 \\ 2 & 85.00 & 88.00 & 83.00 & 87.00 \\ 3 & 51.00 & 75.00 & 73.00 & 71.00 \\ 4 & 74.00 & & 19.00 & 49.00 \\ 5 & 87.00 & 62.00 & 72.00 & 79.00 \\ 6 & 89.00 & 97.00 & 17.00 & 90.00 \\ 7 & 51.00 & 68.00 & 75.00 & 77.00 \\ 8 & 93.00 & 89.00 & 97.00 & 93.00 \\ 9 & 79.00 & 86.00 & 31.00 & 69.00 \\ 10 & 30.00 & 64.00 & 70.00 & 46.00 \\ 11 & 57.00 & 48.00 & 73.00 & 67.00 \\ 12 & 76.00 & 82.00 & 89.00 & 84.00 \\ 13 & 84.00 & 83.00 & 90.00 & 38.00 \\ 14 & 63.00 & 77.00 & 86.00 & 64.00 \\ 15 & 87.00 & 57.00 & 90.00 & 73.00 \\ 16 & 93.00 & 91.00 & 34.00 & 89.00 \\ & & & & \\ \text { Mean } & 71.47 & 75.00 & 67.06 & 68.69 \\ \text { StdDev } & 19.16 & 14.43 & 26.58 & 20.03 \\ \text { SE } & 4.79 & 3.73 & 6.65 & 5.01 \\ \text { Maximum } & 93.00 & 97.00 & 97.00 & 93.00 \\ \text { Minimum } & 30.00 & 48.00 & 17.00 & 25.00\end{array}$


Table 10 (continued)

\section{Contentment}

\begin{tabular}{lrrrr} 
SS & \multicolumn{1}{l}{ Pla } & \multicolumn{1}{c}{ Alc } & THC & Alc/THC \\
& & & & \\
1 & 38.00 & 48.00 & 62.00 & 38.00 \\
2 & 79.00 & 87.00 & 78.00 & 88.00 \\
3 & 60.00 & 71.00 & 68.00 & 64.00 \\
4 & 71.00 & .00 & 36.00 & 73.00 \\
5 & 78.00 & 73.00 & 59.00 & 66.00 \\
6 & 76.00 & 81.00 & 56.00 & 76.00 \\
7 & 56.00 & 66.00 & 44.00 & 56.00 \\
8 & 92.00 & 90.00 & 96.00 & 85.00 \\
9 & 87.00 & 84.00 & 78.00 & 87.00 \\
10 & 46.00 & 75.00 & 71.00 & 35.00 \\
11 & 64.00 & 54.00 & 66.00 & 56.00 \\
12 & 72.00 & 84.00 & 76.00 & 78.00 \\
13 & 76.00 & 81.00 & 85.00 & 61.00 \\
14 & 58.00 & 77.00 & 76.00 & 68.00 \\
15 & 88.00 & 73.00 & 72.00 & 51.00 \\
16 & 68.00 & 83.00 & 46.00 & 80.00 \\
& & & & \\
Mean & 69.34 & 74.99 & 66.80 & 66.36 \\
StdDev & 15.09 & 11.78 & 15.82 & 16.31 \\
SE & 3.77 & 3.04 & 3.95 & 4.08 \\
Maximum & 92.00 & 90.00 & 96.00 & 88.00 \\
Minimum & 38.00 & 48.00 & 36.00 & 35.00
\end{tabular}




\section{APPENDIX B}

\section{Statistical Analyses}


Table 1 Blood Alcohol Concentration

\begin{tabular}{|c|c|c|c|c|c|c|c|c|c|}
\hline \multicolumn{10}{|c|}{ Paired Samples Test } \\
\hline \multirow[b]{2}{*}{$\begin{array}{l}\text { Treatment } \\
\text { pairs }\end{array}$} & \multirow{3}{*}{$\begin{array}{c}\text { Time after } \\
\text { ethanol } \\
\text { administration }\end{array}$} & \multicolumn{5}{|c|}{ Paired Differences } & \multirow[t]{3}{*}{$\mathbf{t}$} & \multirow[t]{3}{*}{ df } & \multirow[t]{3}{*}{ Sig. (2-tailed) } \\
\hline & & Mean & SD & SE & \multicolumn{2}{|c|}{$\begin{array}{l}95 \% \text { Confidence Interval } \\
\text { of the Difference }\end{array}$} & & & \\
\hline & & & & & Lower limit & Upper limit & & & \\
\hline $\begin{array}{l}\text { alc vs } \\
\text { alc/the }\end{array}$ & $1 \mathrm{H} 10$ & .0018 & .0054 & .0014 & -.0011 & .0046 & 1.288 & 15 & .217 \\
\hline $\begin{array}{l}\text { alc vs } \\
\text { ald } / \text { thc }\end{array}$ & $1 \mathrm{H} 50$ & .0013 & .0113 & .0028 & -.0048 & .0073 & .442 & 15 & .665 \\
\hline
\end{tabular}

Table 2 Feelings of Intoxication

Friedman

$\begin{array}{lllllllll} & \mathrm{N} & \text { df } & \text { Pla } & \text { Alc } & \text { THC } & \text { Alc/THC } & \chi^{2} & \text { Sig. } \\ \text { Feeling of High } \mathrm{t}=1 \mathrm{H} 10 & 16 & 3 & 2.00 & 1.97 & 3.06 & 2.97 & 10.940 & .012 \\ \text { Feeling of High } \mathrm{t}=1 \mathrm{H} 50 & 15 & 3 & 1.93 & 1.70 & 3.23 & 3.13 & 18.453 & .000 \\ \text { Feeling of Drunkness } \mathrm{t}=1 \mathrm{H} 10 & 16 & 3 & 1.69 & 3.13 & 1.53 & 3.66 & 34.993 & .000 \\ \text { Feeling of Drunkness } \mathrm{t}=1 \mathrm{H} 50 & 16 & 3 & 1.77 & 3.00 & 1.53 & 3,70 & 31.622 & .000\end{array}$

Wilcoxon Signed Ranks Test

Feeling of High ( $t=1 \mathrm{H10}$ : before driving)

Mean Rank Sum of Ranks Z Asymp. Sig

$\begin{array}{llrrrrl} & & & & & \text { (2-tailed) } \\ \text { Pla -Alc } & \text { Negative Ranks } & 6 & 4.25 & 25.50 & -.204 & .838 \\ & \text { Positive Ranks } & 4 & 7.38 & 29.50 & & \\ & \text { Ties } & 6 & & & & \\ & \text { Total } & 16 & & & & \\ & \text { Negative Ranks }- \text { THC } & 3 & 4.00 & 12.00 & -2.897 & .004 \\ & \text { Positive Ranks } & 13 & 9.54 & 124.00 & & \\ & \text { Ties } & 0 & & & & \\ \text { Pla -Ald/THC } & \text { Total } & \text { Negative Ranks } & 16 & & & \\ & \text { Positive Ranks } & 12 & 10.08 & 121.00 & & \\ & \text { Ties } & 0 & & & & \end{array}$

Feeling of High ( $t=1 \mathrm{H50}$ : after driving)

\begin{tabular}{llrllll}
\multirow{5}{*}{ Pla - Alc } & N & Mean Rank & Sum of Ranks & $Z$ & $\begin{array}{l}\text { Asymp. Sig } \\
\text { (2-tailed) }\end{array}$ \\
& Negative Ranks & 5 & 5.00 & 25.00 & -.980 & .327 \\
& Positive Ranks & 3 & 3.67 & 11.00 & & \\
& Ties & 7 & & & & \\
Pla - THC & Total & 15 & & & & \\
& Negative Ranks & 3 & 5.33 & 16.00 & -2.500 & .012 \\
& Positive Ranks & 12 & 8.67 & 104.00 & & \\
Pla - Alc/THC & Ties & 1 & & & & \\
& Total & 16 & & & & \\
& Negative Ranks & 3 & 5.33 & 16.00 & -2.691 & .007 \\
& Positive Ranks & 13 & 9.23 & 120.00 & & \\
& Ties & 0 & & & &
\end{tabular}


Table 2 (continued)

Feeling of drunkness ( $t=1$ H10 : before driving)

\begin{tabular}{|c|c|c|c|c|c|c|}
\hline ל & & $\mathbf{N}$ & Mean Rank & Sum of Ranks & $\mathbf{Z}$ & $\begin{array}{l}\text { Asymp. Sig } \\
\text { (2-tailed) }\end{array}$ \\
\hline \multirow[t]{4}{*}{ Pla - Alc } & Negative Ranks & 0 & .00 & .00 & -3.408 & .001 \\
\hline & Positive Ranks & 15 & 8.00 & 120.00 & & \\
\hline & Ties & 1 & & & & \\
\hline & Total & 16 & & & & . \\
\hline \multirow[t]{4}{*}{ Pla - THC } & Negative Ranks & 5 & 3.60 & 18.00 & -.677 & .498 \\
\hline & Positive Ranks & 2 & 5.00 & 10.00 & & \\
\hline & Ties & 9 & & & & \\
\hline & Total & 16 & & & & . \\
\hline \multirow[t]{4}{*}{ Pla - Alc/THC } & Negative Ranks & 0 & .00 & .00 & -3.296 & .001 \\
\hline & Positive Ranks & 14 & 7.50 & 105.00 & & \\
\hline & Ties & 2 & & & & \\
\hline & Total & 16 & & & & $\ldots$ \\
\hline \multicolumn{5}{|c|}{ Feeling of drunkness ( $t=1 \mathrm{H50}:$ after driving) } & & $\therefore \quad \therefore \quad$ \\
\hline & & $\mathrm{N}$ & Mean Rank & Sum of Ranks & $\mathrm{Z}$ & $\begin{array}{l}\text { Asymp. Sig } \\
\text { (2-tailed) }\end{array}$ \\
\hline \multirow[t]{4}{*}{ Pla - Alc } & Negative Ranks & 0 & .00 & .00 & -3.182 & .001 \\
\hline & Positive Ranks & 13 & 7.00 & 91.00 & & \\
\hline & Ties & 2 & & & & $\therefore$ \\
\hline & Total & 15 & & & & \\
\hline \multirow[t]{4}{*}{ Pla - THC } & Negative Ranks & 6 & 4.83 & 29.00 & -1.540 & .123 \\
\hline & Positive Ranks & 2 & 3.50 & 7.00 & $\therefore$ & \\
\hline & Ties & 8 & & & & \\
\hline & Total & 16 & & & & \\
\hline \multirow[t]{4}{*}{$\mathrm{Pla}-\mathrm{Alc} / \mathrm{THC}$} & Negative Ranks & 0 & .00 & .00 & -3.297 & .001 \\
\hline & Positive Ranks & 14 & 7.50 & 105.00 & & \\
\hline & Ties & 2 & & & & $\because$ \\
\hline & Total & 16 & & & & \\
\hline
\end{tabular}


Friedman's test

Total score

Vehicle checks

Vehicle handling

Action in traffic

Observation traffic

Turning

$\begin{array}{llllllll}\mathbf{N} & \text { df } & \text { Pla } & \text { Alc } & \text { THC } & \text { Alc/THC } & \chi^{2} & \text { Asymp. Sig. } \\ 16 & 3 & 2,91 & 2,47 & 2,09 & 2,53 & 3.228 & .358 \\ 16 & 3 & 2,53 & 2,69 & 2,19 & 2,59 & 1,672 & , 643 \\ 16 & 3 & 2,75 & 2,44 & 2,25 & 2,56 & 1,437 & , 697 \\ 16 & 3 & 2,88 & 2,41 & 2,16 & 2,56 & 2,708 & , 439 \\ 16 & 3 & 2,81 & 2,50 & 2,00 & 2,69 & 4.170 & .244 \\ 16 & 3 & 2,34 & 2,75 & 1,97 & 2,94 & 6.331 & .097\end{array}$

Wilcoxon Signed Ranks Test

Total score

Pla - Alc Negative Ranks Positive Ranks Ties

Total

Pla - THC Negative Ranks

Positive Ranks

Ties

Total

Pla-Alc/THC Negative Ranks

Positive Ranks

Ties

Total

$\begin{array}{rllll}\mathrm{N} & \text { Mean Rank } & \text { Sum of Ranks } & \mathrm{Z} & \begin{array}{c}\text { Asymp. Sig } \\ \text { (2-tailed) }\end{array} \\ 11 & 7,95 & 87,50 & -1.011 & .312 \\ 5 & 9,70 & 48,50 & & \\ 0 & & & & \\ 16 & & & & \\ 11 & 8,41 & 92,50 & -1.847 & .065 \\ 4 & 6,88 & 27,50 & & \\ 1 & & & & \\ 16 & & & & \\ 8 & 9,69 & 77,50 & -.4 .92 & .623 \\ 8 & 7,31 & 58,50 & & \\ 0 & & & & \end{array}$

Subscore : Vehicle checks

$N$

Mean Rank Sum of Ranks

Z Asymp. Sig (2-tailed)

Pla - Alc Negative Ranks Positive Ranks

Ties

Total

Pla - THC Negative Ranks

Positive Ranks

Ties

Total

Pla-Alc/THC Negative Ranks

Positive Ranks

Ties

Total

5,80

6,17

29,00

37,00

$-.359 \quad .720$

5
5
16

16

7

5,57

39,00

$-1.184 \quad .237$

5,33

16,00

6

16

5

7,30

36,50

41,50

$-.203 \quad .839$ 
Table 3

(continued)

Subscore : Vehicle handling

\begin{tabular}{|c|c|c|c|c|c|c|}
\hline & & $\mathbf{N}$ & Mean Rank & Sum of Ranks & $Z$ & $\begin{array}{l}\text { Asymp. Sig } \\
\text { (2-tailed) }\end{array}$ \\
\hline \multirow[t]{4}{*}{ Pla - alc } & Negative Ranks & 7 & 5,71 & 40,00 & -.625 & .532 \\
\hline & Positive Ranks & 4 & 6,50 & 26,00 & & \\
\hline & Ties & 5 & & & & \\
\hline & Total & 16 & & & & \\
\hline \multirow[t]{4}{*}{ Pla - THC } & Negative Ranks & 7 & 6,71 & 47,00 & -1.252 & .210 \\
\hline & ositive Ranks & 4 & 4,75 & 19,00 & & \\
\hline & Ties & 5 & & & & \\
\hline & Total & 16 & & & & \\
\hline \multirow[t]{4}{*}{$\mathrm{Pla}-\mathrm{Alc} / \mathrm{THC}$} & Negative Ranks & 9 & 7,00 & 63,00 & -.260 & .795 \\
\hline & ositive Ranks & 7 & 10,43 & 73,00 & & \\
\hline & Ties & 0 & & & & \\
\hline & Total & 16 & & & & \\
\hline
\end{tabular}

Subscore : Traffic maneuvers

\begin{tabular}{llrllll} 
Pla - alc & Negative Ranks & 10 & 8,20 & 82,00 & -1.259 & .208 \\
& Positive Ranks & 5 & 7,60 & 38,00 & & \\
& Ties & 1 & & & & \\
\multirow{5}{*}{ Pla - THC } & Total & 16 & & & & \\
& Negative Ranks & 10 & 8,20 & 82,00 & -1.257 & .209 \\
& ositive Ranks & 5 & 7,60 & 38,00 & & \\
& Ties & 1 & & & & \\
Pla - Alc/THC & Total & 16 & & & & \\
& Negative Ranks & 9 & 10,61 & 95,50 & & \\
& Positive Ranks & 7 & 5,79 & 40,50 & & \\
& Ties & 0 & & & &
\end{tabular}

Subscore : Observation and understanding traffic

\begin{tabular}{|c|c|c|c|c|c|c|}
\hline & & $\mathrm{N}$ & Mean Rank & Sum of Ranks & $Z$ & $\begin{array}{l}\text { Asymp. Sig } \\
\text { (2-tailed) }\end{array}$ \\
\hline \multirow[t]{4}{*}{ Pla-Alc } & Negative Ranks & 9 & 6,33 & 57,00 & \multirow[t]{4}{*}{-.286} & \multirow[t]{4}{*}{.775} \\
\hline & ositive Ranks & 5 & 9,60 & 48,00 & & \\
\hline & Ties & 2 & & & & \\
\hline & Total & 16 & & & & \\
\hline \multirow{4}{*}{$\mathrm{Pla}$ - THC } & Negative Ranks & 9 & 5,78 & 52,00 & \multirow[t]{4}{*}{-1.707} & \multirow[t]{4}{*}{.088} \\
\hline & ositive Ranks & 2 & 7,00 & 14,00 & & \\
\hline & Ties & 5 & & & & \\
\hline & Total & 16 & & & & \\
\hline \multicolumn{2}{|c|}{ Pla - Alc/THC Negative Ranks } & 6 & 7,25 & 43,50 & \multirow[t]{4}{*}{-.140} & \multirow[t]{4}{*}{.888} \\
\hline & Positive Ranks & 7 & 6,79 & 47,50 & & \\
\hline & Ties & 3 & & & & \\
\hline & Total & 16 & & & & \\
\hline
\end{tabular}


Subscore : Special maneuvers

\begin{tabular}{|c|c|c|c|c|c|c|}
\hline$\therefore$ & & $\mathbf{N}$ & Mean Rank & Sum of Ranks & $\mathbf{Z}$ & $\begin{array}{l}\text { Asymp. Sig } \\
\text { (2-tailed) }\end{array}$ \\
\hline Pla - Alc & $\begin{array}{l}\text { Negative Ranks } \\
\text { ositive Ranks } \\
\text { Ties } \\
\text { Total }\end{array}$ & $\begin{array}{r}3 \\
8 \\
5 \\
16\end{array}$ & $\begin{array}{l}6,67 \\
5,75\end{array}$ & $\begin{array}{l}20,00 \\
46,00\end{array}$ & -1.182 & .237 \\
\hline Pla-THC & $\begin{array}{l}\text { Negative Ranks } \\
\text { ositive Ranks } \\
\text { Ties } \\
\text { Total }\end{array}$ & $\begin{array}{r}9 \\
4 \\
3 \\
16\end{array}$ & $\begin{array}{l}6,33 \\
8,50\end{array}$ & $\begin{array}{l}57,00 \\
34,00\end{array}$ & -.836 & .403 \\
\hline Pla - Alc/THC & $\begin{array}{l}\text { Negative Ranks } \\
\text { ositive Ranks } \\
\text { Ties } \\
\text { Total }\end{array}$ & $\begin{array}{r}3 \\
8 \\
5 \\
16\end{array}$ & $\begin{array}{l}6,50 \\
5,81\end{array}$ & $\begin{array}{l}19,50 \\
46,50\end{array}$ & -1.215 & .224 \\
\hline
\end{tabular}

Table $4 \quad$ Visual search at intersections

Friedman's Test

$\begin{array}{lllllllll} & \mathrm{N} & \mathrm{df} & \mathrm{Pla} & \mathrm{Alc} & \mathrm{THC} & \text { Alc/THC } & \chi^{2} & \text { Asymp. Sig. } \\ \text { Visual search at intersections } & 16 & 3 & 2.88 & 2.81 & 2.41 & 1.91 & 5.866 & .118\end{array}$

Wilcoxon Signed Ranks Test

\begin{tabular}{|c|c|c|c|c|c|c|}
\hline & & $\mathbf{N}$ & Mean Rank & Sum of Ranks & $Z$ & $\begin{array}{l}\text { Asymp. Sig } \\
\text { (2-tailed) }\end{array}$ \\
\hline \multirow[t]{4}{*}{ Pla - Alc } & Negative Ranks & 6 & 9,25 & 55,50 & -.257 & .797 \\
\hline & Positive Ranks & 9 & 7,17 & 64,50 & & \\
\hline & Ties & 1 & & & & \\
\hline & Total & 16 & & & & \\
\hline \multirow[t]{4}{*}{ Pla - THC } & Negative Ranks & 11 & 6,95 & 76,50 & -.440 & .660 \\
\hline & Positive Ranks & 5 & 11,90 & 59,50 & & \\
\hline & Ties & 0 & & & & \\
\hline & Total & & 16 & & & \\
\hline \multirow[t]{4}{*}{$\mathrm{Pla}-\mathrm{Alc} / \mathrm{THC}$} & Negative Ranks & 12 & 8,00 & 96,00 & -2.048 & .041 \\
\hline & Positive Ranks & 3 & 8,00 & 24,00 & & \\
\hline & Ties & 1 & & & & \\
\hline & Total & 16 & & & & \\
\hline
\end{tabular}

Mann-Whitney Test (Gender X Treatment)

\begin{tabular}{|c|c|c|c|c|c|c|c|}
\hline & $\mathbf{N}$ & $\begin{array}{l}\text { Mean } \\
\text { Rank }\end{array}$ & $\begin{array}{l}\text { Sum of } \\
\text { Ranks }\end{array}$ & $\begin{array}{l}\text { Mann- } \\
\text { Whitney U }\end{array}$ & Wilcoxon W & $\mathbf{Z}$ & Sig \\
\hline \multicolumn{8}{|c|}{ Pla - Alc } \\
\hline male & 8 & 10,50 & 84,00 & 16.00 & 52.00 & -1.693 & .090 \\
\hline female & 8 & 6,50 & 52,00 & & & & \\
\hline Total & 16 & & & & & & \\
\hline
\end{tabular}




\section{N Mean Sum of \\ Rank}

Pla - THC

$\begin{array}{llll}\text { man } & 8 & 10,31 & 82,50 \\ \text { female } & 8 & 6,69 & 53,50 \\ \text { Total } & 16 & & \end{array}$

Pla - Alc/THC

$\begin{array}{llllllll}\text { man } & 8 & 10,50 & 84,00 & 16.00 & 52.00 & -1.687 & .092 \\ \text { vrouw } & 8 & 6,50 & 52,00 & & & & \\ \text { Total } & 16 & & & & & & \end{array}$

\section{Table 5 Route recognition test}

Friedman Test

$\begin{array}{lllllllll} & \mathrm{N} & \mathrm{df} & \mathrm{Pla} & \text { Alc } & \text { THC } & \text { Alc/THC } & \chi 2 & \text { Asymp. Sig, } \\ \text { Photo's recognized by subjects } & 13 & 3 & 3,00 & 2,12 & 2,42 & 2,46 & 3,369 & \mathbf{3 3 8}\end{array}$

Wilcoxon Signed Ranks Test

\begin{tabular}{|c|c|c|c|c|c|c|}
\hline & 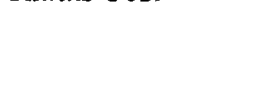 & $\mathbf{N}$ & Mean Rank & Sum of Ranks & $\mathrm{Z}$ & $\begin{array}{l}\text { Asymp. Sig } \\
\text { (2-tailed) }\end{array}$ \\
\hline \multirow[t]{4}{*}{ Pla - Alc } & Negative Ranks & 8 & 5,94 & 47,50 & $-2,059$ & ,040 \\
\hline & Positive Ranks & 2 & 3,75 & 7,50 & & \\
\hline & Ties & 3 & & & & \\
\hline & Total & 13 & & & & \\
\hline \multirow[t]{4}{*}{$\mathrm{Pla}-\mathrm{THC}$} & Negative Ranks & 8 & 6,38 & 51,00 &,- 948 &, 343 \\
\hline & Positive Ranks & 4 & 6,75 & 27,00 & & \\
\hline & Ties & 1 & & & & \\
\hline & Total & 13 & & & & \\
\hline \multirow[t]{4}{*}{$\mathrm{Pla}$ - Alc/THC } & Negative Ranks & 7 & 6,36 & 44,50 & $-1,030$ & ,303 \\
\hline & Positive Ranks & 4 & 5,38 & 21,50 & & \\
\hline & Ties & 2 & & & & \\
\hline & Total & 13 & & & & \\
\hline
\end{tabular}

Mann-

Whitney U

17.50

53.50

$-1.526 \quad .127$

3,50

Wilcoxon W

Z Sig

.127 
Table $6 \quad$ Perceived driving quality

Friedman's test

$\begin{array}{lllllllll} & \mathrm{N} & \mathrm{df} & \mathrm{Pla} & \text { Alc } & \text { THC } & \text { Alc/THC } & \chi^{2} & \text { Asymp. Sig. } \\ \text { Perceived driving quality } & 14 & 3 & 2.89 & 2.61 & 2.07 & 2.43 & 3.044 & .385\end{array}$

Wilcoxon Signed Ranks Test

\begin{tabular}{|c|c|c|c|c|c|c|}
\hline & & $\mathbf{N}$ & Mean Rank & Sum of Ranks & $\mathbf{Z}$ & $\begin{array}{l}\text { Asymp. Sig } \\
\text { (2-tailed) }\end{array}$ \\
\hline \multirow[t]{4}{*}{ Pla - Alc } & Negative Ranks & 9 & 7,44 & 67,00 & -.398 & .691 \\
\hline & Positive Ranks & 6 & 8,83 & 53,00 & & \\
\hline & Ties & 0 & & & & \\
\hline & Total & 15 & & & & \\
\hline \multirow[t]{4}{*}{ Pla - THC } & Negative Ranks & 12 & 9,71 & 116,50 & -2.510 & .012 \\
\hline & Positive Ranks & 4 & 4,88 & 19,50 & & \\
\hline & Ties & 0 & & & & \\
\hline & Total & 16 & & & & \\
\hline \multirow[t]{4}{*}{$\mathrm{Pla}$ - Alc/THC } & Negative Ranks & 8 & 6,94 & 55,50 & -.699 & .485 \\
\hline & Positive Ranks & 5 & 7,10 & 35,50 & & \\
\hline & Ties & 2 & & & & \\
\hline & Total & 15 & & & & \\
\hline
\end{tabular}

Table $7 \quad$ Perceived Effort

Friedman's test

Effort

$\begin{array}{llllllll}\mathrm{N} & \mathrm{df} & \text { Pla } & \text { Alc } & \text { THC } & \text { Alc/THC } \chi^{2} & \text { Asymp. Sig. } \\ 15 & 3 & 2.07 & 2.03 & 3.17 & 2.73 & 8.195 & .042\end{array}$

Wilcoxon Signed Ranks Test

\begin{tabular}{|c|c|c|c|c|c|c|}
\hline & & & 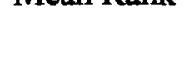 & 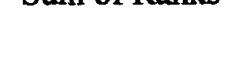 & & (2-tailed) \\
\hline \multirow[t]{4}{*}{ Pla - Alc } & Negative Ranks & 8 & 8,75 & 70,00 & -.568 & .570 \\
\hline & Positive Ranks & 7 & 7,14 & 50,00 & & \\
\hline & Ties & 0 & & & & \\
\hline & Total & 15 & & & & \\
\hline \multirow[t]{4}{*}{ Pla - THC } & Negative Ranks & 4 & 5,75 & 23,00 & -2.327 & .020 \\
\hline & Positive Ranks & 12 & 9,42 & 113,00 & & \\
\hline & Ties & 0 & & & & \\
\hline & Total & 16 & & & & \\
\hline \multirow[t]{4}{*}{$\mathrm{Pla}-\mathrm{Alc} / \mathrm{THC}$} & Negative Ranks & 4 & 10,13 & 40,50 & -1.422 & .155 \\
\hline & Positive Ranks & 12 & 7,96 & 95,50 & & \\
\hline & Ties & $\mathbf{0}$ & & & & \\
\hline & Total & 16 & & & & \\
\hline
\end{tabular}


Table $8 \quad$ Willingness to drive

Cochran Q-Test

Circumstance $A$ : unimportant

\begin{tabular}{lrrrrrl} 
& \multicolumn{2}{c}{ Value } & $\mathrm{N}$ & $\mathrm{df}$ & Cochran's Q & Asymp. Sig \\
Overall & \multicolumn{1}{c}{ O } & 1 & & & & \\
Pla & 4 & 12 & 16 & 3 & 13,533 & .004 \\
Alc & 9 & 7 & 16 & 1 & 2.778 & .096 \\
THC & 10 & 6 & 16 & 1 & 3.600 & .058 \\
Alc/THC & 14 & 2 & 16 & 1 & 10.000 & .002
\end{tabular}

Cirumstance B : important

Value $\mathrm{N}$ df Cochran's $\mathrm{Q}$ Asymp. Sig

$\begin{array}{lllll}\text { Overall } & 16 & 3 & 14,163 & , 003\end{array}$

Alc

THC

Alc/THC

$2 \quad 14$

$7 \quad 9$

$\begin{array}{rr}6 & 10 \\ 12 & 4\end{array}$

Circumstance $C$ : urgent

$$
\text { Value }
$$

Overall

$\mathrm{Pla}$

Alc

THC

Alc/THC

$\begin{array}{ll}0 & 1 \\ 1 & 15 \\ 1 & 15 \\ 5 & 11\end{array}$

1

$\mathrm{N} \quad \mathrm{df}$

16

$15 \quad 16$

15

11

16
16
16

3.571

2.667

.059

.102

.002

$10.000-.002$ 
Table 9 : $\quad$ Bond and lader: alertness. contentment and calmness

Friedman's test

$\begin{array}{lllllllll} & \mathrm{N} & \mathrm{df} & \mathrm{Pla} & \text { Alc } & \text { THC } & \text { Alc/THC } & \chi 2 & \text { Asymp. Sig. } \\ \text { Alertness } & 15 & 3 & 2.80 & 3.33 & 1.73 & 2.13 & 13.560 & .004 \\ \text { Contentment } & 15 & 3 & 2.27 & 3.20 & 2.33 & 2.20 & 6.041 & .110 \\ \text { Calmness } & 15 & 3 & 2.20 & 2.53 & 2.93 & 2.33 & 2.760 & .430\end{array}$

Wilcoxon Signed Ranks Test

\section{Alertness}

Pla - Alc

Negative Ranks

Positive Ranks

Ties

Total

Pla - THC Negative Ranks

Positive Ranks

Ties

Total

Pla- Alc/THC

Negative Ranks

Positive Ranks

Ties

Total
N Mean Rank Sum of Ranks $Z \quad \begin{gathered}\text { Asymp. Sig } \\ \text { (2-tailed) }\end{gathered}$

$\begin{array}{rrrrr}5 & 7.20 & 36.00 & -1.363 & .173 \\ 10 & 8.40 & 84.00 & & \\ 0 & & & & \\ 15 & & 115.00 & -2.430 & .015 \\ 12 & 9.58 & 21.00 & & \\ 4 & 5.25 & & & \\ 0 & & 107.00 & -2.017 & .044 \\ 16 & & 29.00 & & \\ 12 & 8.92 & & & \\ 4 & 7.25 & & & \\ 0 & & & & \end{array}$

\section{Contentment}

Pla - Alc Negative Ranks Positive Ranks

Ties

Total

Pla - THC

Negative Ranks Positive Ranks

Ties

Total

Pla-Alc/THC Negative Ranks Positive Ranks

Ties

Total

\section{Calmness}

Pla - Alc Negative Ranks Positive Ranks Ties

Total

Pla- THC Negative Ranks Positive Ranks Ties Total

Pla- Alc/THC

$N$

Mean Rank

7.00

8.67

10.83

7.10

10

0

16
Sum of Ranks

Z Asymp. Sig

42.00

78.00

65.00

$-.155 \quad .877$

62.00

$-.597 \quad .551$

Z Asymp. Sig

$-1.762 \quad .078$

$-.465 \quad .642$

77.00
59.00

71.00

73.00

$-.259 \quad .796$ Positive Ranks Ties

Total 


\section{APPENDIX C}

\section{ANWB Driving Proficiency Test}




\section{ANWB}

DRIVING PROFICIENCY TEST

\section{TRAFFIC DEPARTMENT}

This is a translation of the shortened version of the Royal Dutch Tourist Association (ANWB) Proficiency Driving Test

Pass

Fail

I Vehicle checks

01 Preparing to drive off

01.1 Position of driver's seat

01.2 Instrument check

01.3 Starting the engine

01.4 Use of safety belt

01.5 checking mirrors

01.6 Proper use of lights

$\begin{array}{lll}\text { X } & & \text { X } \\ & \text { X } & \text { X } \\ \text { X } & & \text { X } \\ \text { X } & & \text { X } \\ \text { X } & & \text { X } \\ \text { X } & & \text { X } \\ \text { X } & & \text { X }\end{array}$

02 Driving off

02.1 Checking position of hand-brake

02.2 Looking ahead, to the side and to the rear before driving off

02.3 Selecting correct position in traffic lane

02.4 Adapting speed immediately to traffic flow

02.5 Re-checking mirrors

$\begin{array}{ll}\mathbf{X} & \mathbf{X} \\ \mathbf{X} & \mathbf{X} \\ \mathbf{X} & \mathbf{X} \\ \mathbf{X} & \mathbf{X} \\ \mathbf{X} & \mathbf{X}\end{array}$

\section{Handling of vehicle}

03 Manner of sitting behind the wheel, and steering

03.1 Manner of sitting behind the wheel when driving

03.2 Position of hands on the wheel

03.2a Taking hands of the steering wheel whilst gesticulating (???)

03.3 Steering through curves

03.4 Position of head whilst talking to passengers

$\begin{array}{ccc} & \mathbf{X} & \mathbf{X} \\ \mathbf{X} & & \mathbf{X} \\ \mathbf{X} & & \mathbf{X} \\ & \mathbf{X} & \mathbf{X} \\ \mathbf{X} & & \mathbf{X}\end{array}$

04 Handling of controls

04.1 Accelerator

04.2 Foot-brake

04.3 Hand-brake

04.4 Clutch-pedal

04.5 Gear-level

$\begin{array}{ll}\mathbf{X} & \mathbf{X} \\ \mathbf{X} & \mathbf{X} \\ \mathbf{X} & \mathbf{X} \\ \mathbf{X} & \mathbf{X} \\ \mathbf{X} & \mathbf{X}\end{array}$

05 Speed control, deceleration and stopping

05.1 Choice of speed in view of circumstances

05.2 Use of accelerator and brake

05.3 Use of mirrors before and during deceleration

05.4 Indication of deceleration in good time by use of stop-lights

05.5 Correct sequence of manoeuvres for deceleration

05.6 Declutch at the correct stage and put gear-lever in neutral

05.7 Come to a stop smoothly

05.8 Clutch not depressed whilst waiting

$\begin{array}{ccc}\text { X } & & \text { X } \\ \text { X } & & \text { X } \\ \text { X } & & \text { X } \\ \text { X } & & \text { X } \\ & \text { X } & \text { X } \\ \text { X } & & \text { X } \\ \text { X } & & \text { X } \\ \text { X } & & \text { X }\end{array}$


06 Taking corners

06.1 Safe starting speed

06.2 Selecting correct gear before entering corner

06.3 Without slipping clutch or foot on the clutch-pedal

06.4 No braking in corner

06.5 No free-wheeling

06.6 Correct drive line

$\begin{array}{ll}\mathbf{X} & \text { X } \\ \mathbf{X} & \text { X } \\ \mathbf{X} & \text { X } \\ \text { X } & \text { X } \\ \text { X } & \text { X } \\ \text { X } & \text { X }\end{array}$

\section{Action in traffic}

07 Driving straight

07.1 Keeping to the right

07.2 Adapting speed to that of other similar traffic

07.3 Looking into side streets

$\begin{array}{ll}\mathrm{X} & \mathrm{X} \\ \mathrm{X} & \mathrm{X}\end{array}$

07.4 Taking into account blind spots caused by car design and passengers

07.5 Taking into account limitation of mirrors

07.6 Keeping distance from traffic in front

07.7 Driving in offset position with regard to preceding vehicle

07.8 Pedestrian crossing

07.9 Watching for pedestrians crossing the road (at other places than at zebra crossings)

$\mathrm{X}$

$$
\begin{aligned}
& \mathbf{X} \\
& \mathbf{X} \\
& \mathbf{X} \\
& \mathbf{X} \\
& \mathbf{X}
\end{aligned}
$$

\section{Behavior at or near crossroads}

08.1 Judging the situation beforehand

08.2 Behavior at the approach to traffic lights

08.3 Driving in traffic lanes marked with arrows, and according to other indications on road surface

08.4 Taking position in traffic lanes marked with arrows

08.5 Bicycle and bus lanes

08.6 Consideration of other drivers

08.7 Complying with priority rules

$\begin{array}{ccc} & \text { X } & \text { X } \\ & \text { X } & \text { X } \\ & & \\ \mathbf{X} & & \text { X } \\ \mathbf{X} & & \text { X } \\ \text { X } & & \text { X } \\ \text { X } & & \text { X } \\ \text { X } & & \text { X }\end{array}$

\section{$09 \quad$ Right-hand turn}

09.1 Taking position in good time when filtering (selection of correct lane)

09.2 Looking behind and to the right

09.3 Switching on direction indicators

09.4 Positive filtering and in good time, adapting speed

09.5 Looking over right shoulder

09.6 Not impeding traffic that continues straight ahead

09.7 Final check

09.8 Taking corner as closely as possible

$\begin{array}{ll}\text { X } & \text { X } \\ \text { X } & \text { X } \\ \text { X } & \text { X } \\ \text { X } & \text { X } \\ \text { X } & \text { X } \\ \text { X } & \text { X } \\ \text { X } & \text { X } \\ \text { X } & \text { X }\end{array}$

10 Left -hand turn

10.1 Taking position in good time when filtering (selection of correct lane)

10.2 Looking to the rear, rear left and left

10.3 Switching on direction indicators

10.4 Positive filtering and in good time, adapting speed

$\begin{array}{ll}X & X \\ X & X \\ X & X \\ X & X\end{array}$


10.5 Not impeding traffic that continues straight ahead

$\begin{array}{ll}\mathbf{X} & \mathbf{X} \\ \mathbf{X} & \mathbf{X} \\ \mathbf{X} & \mathbf{X} \\ \mathbf{X} & \mathbf{X}\end{array}$

10.7 Final check

10.8 Taking a sufficiently wide corner

$\mathbf{X}$

\section{Traffic lane technique}

11.1 Keeping well within lane

11.2 Checking traffic before leaving lane

11.3 Changing traffic lanes one at a time

11.4 Driving straight, avoiding minor deviations

11.5 Driving in lines abreast

$\begin{array}{ll}\mathbf{X} & \mathbf{X} \\ \mathbf{X} & \mathbf{X} \\ \mathbf{X} & \mathbf{X} \\ \mathbf{X} & \mathbf{X} \\ \mathbf{X} & \mathbf{X}\end{array}$

12 Driving on traffic circles

12.1 Observation (dividing attention)

12.2 Using direction indicators during the entire maneuver

12.3 Correct positioning for turning in good time

12.4 Selecting and driving in the correct traffic lane

12.5 Weaving out of the traffic flow correctly and in good time

$\begin{array}{lll} & \text { X } & \text { X } \\ \text { X } & & \text { X } \\ \text { X } & & \text { X } \\ \text { X } & & \text { X } \\ \text { X } & & \text { X }\end{array}$

\section{Observation and understanding of traffic}

\section{Observation}

13.1 Observation technique

13.2 Observation of overall picture of traffic, road and surroundings

13.3 Conscious observation of traffic signs

13.4 Use of direction signs

$\begin{array}{ll}\mathbf{X} & \mathbf{X} \\ \mathbf{X} & \mathbf{X} \\ \mathbf{X} & \mathbf{X} \\ \mathbf{X} & \mathbf{X}\end{array}$

14 Understanding traffic

14.1 Anticipation

14.2 Making allowance for any traffic situations that may occur

14.3 Reactions to observations made

14.4 Strategy

$\begin{array}{ll}\mathbf{X} & \mathbf{X} \\ \mathbf{X} & \mathbf{X} \\ \mathbf{X} & \mathbf{X} \\ \mathbf{X} & \mathbf{X}\end{array}$

\section{Special Maneuvers}

\section{Turning}

15.1 Stopping at the correct place

15.2 Driving slowly, while turning steering wheel rapidly; no use of steering wheel while stopped.

15.3 Looking alongside the car when approaching the kerb

15.4 Observing traffic during the entire manoeuvre

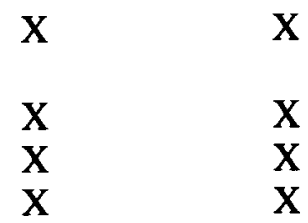

\section{Alighting from car}

16.1 Opening doors (looking for other traffic/obstacles before opening the doors)

$\mathbf{X}$ 
DOT HS 809020

March 2000 